\title{
Performing plague: Antonio Zanchi and the dynamics of spectatorship at the Scuola Grande di San Rocco in Venice
}

\author{
JenNifer Gear
}

\section{INTRODUCTION}

In the lowest register of The Virgin Appears to the Plague-Stricken, a painting by Antonio Zanchi that spans two canvases on the grand stairway of the Scuola Grande di San Rocco in Venice, a disturbing tableau unfolds (Figs. 1-3). Out of the gloom materialize the corpses of a woman and infant, greying and still clasped in an embrace. The darkened spots on their skin signal that they are victims of a plague. Their bodies are foreshortened, with the effect that they seem to project from the canvas, the woman's lifeless, empty face and the child's toes pressing toward the viewer at eye level when seen from the bottom of the stairs. Framing these corpses are a large pilaster and the muscular calves of a body clearer - pizzigamorto in Venetian dialect - who stands in the shallow boat in which the bodies lie. He is collecting the dead for transport to a mass grave on the Lido. The viewer's gaze is assaulted by a third corpse, hanging in the open air off the side of a bridge, moments from being heaved by another sanitation worker into the boat below. Atop the bridge, more infected bodies have been heaped for disposal, the wooden supports of the stretcher used to carry them jutting into the air. An onlooker dressed in black plugs his nose against the polluted air, staring at the grisly spectacle taking place at his feet. His response is blunted by familiarity; he turns his head to glance before exiting the scene.

In this painting the city of Venice, typically rendered in the early modern period as a paragon of order and justice, is depicted as a hellish cityscape, engulfed in the dank clouds of pestilence and filled with scenes of danger and chaos. From the grim scene encountered at the bottom of the stairs, the monumental painting opens out into an expansive but intimate view of Venice at

I would like to thank Megan Holmes for her encouragement and support of this project. Her close reading of early drafts and insightful comments were invaluable to the development of this essay. Thanks also go to Tom Willette and my two anonymous readers whose feedback I appreciate immensely. Research for this work was supported by a generous grant from the Gladys Krieble Delmas Foundation, for which I am grateful. This article is in memory of Brian Curran, who embodied generosity in teaching, mentoring, and scholarship. 


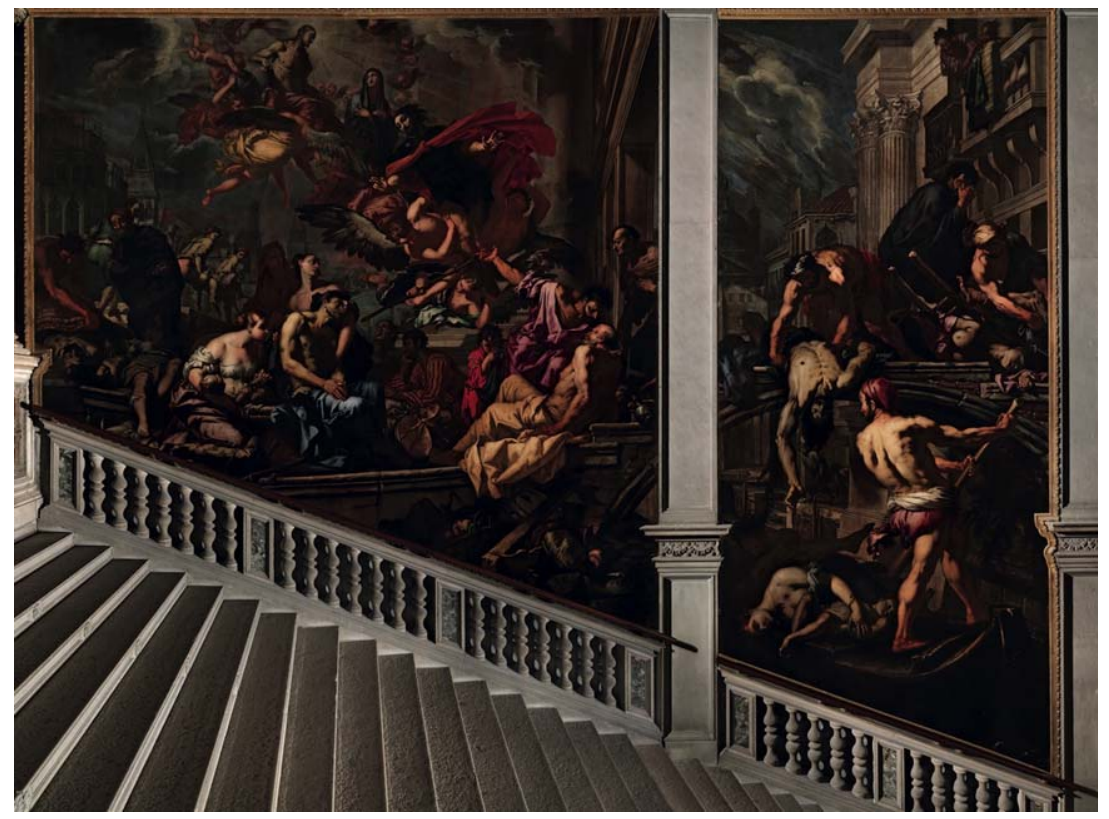

Fig. 1 Antonio Zanchi, 'The Virgin Appears to the Plague-Stricken', 1666, oil on canvas (two canvases separated by a pilaster), $335 \times 555 \mathrm{~cm}$ and $635 \times 705 \mathrm{~cm}$, Scuola Grande di San Rocco, Venice (photo: Scuola Grande di San Rocco)

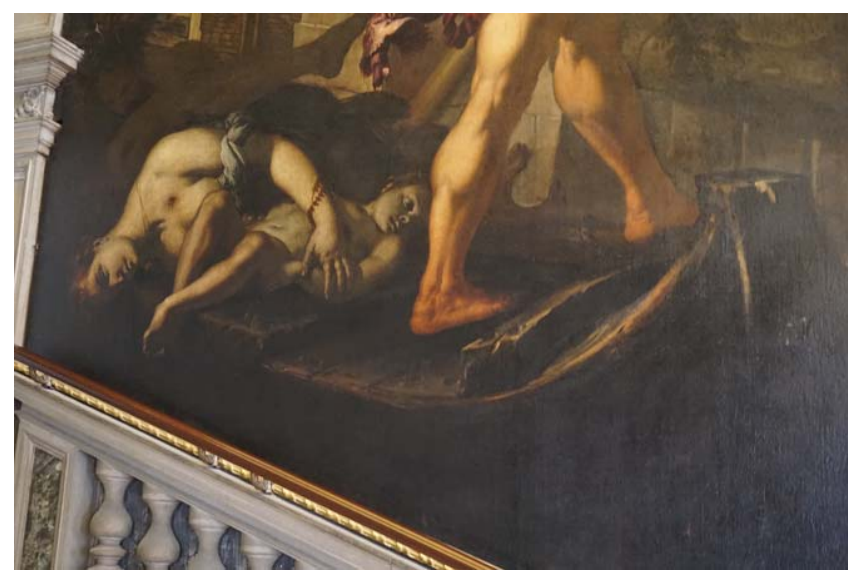

Fig. 2 'The Virgin Appears to the Plague-Stricken', detail (photo: author)

uncomfortably close range - an effect of the shallow pictorial space and the confines of the stairway in which the painting is situated. The scene is peopled with over-life-size actors who, with demonstrative gestures, re-enact the events that had come to define the catastrophic plague outbreak of 1630-31 in 


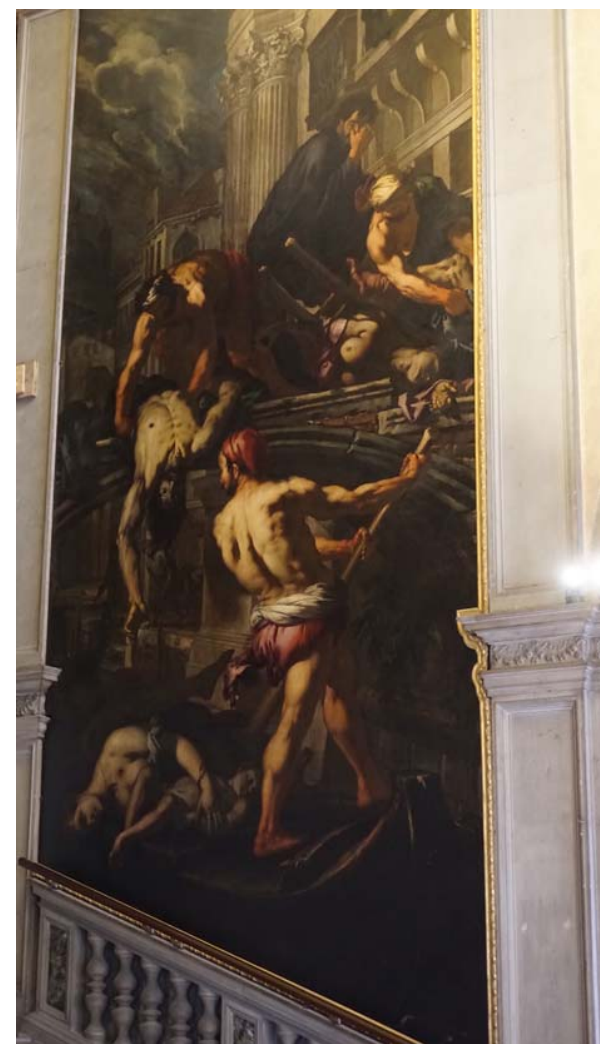

Fig. 3 'The Virgin Appears to the Plague-Stricken', detail (photo: author)

Venice, in which approximately $33 \%$ of the population perished (Fig. 4). ${ }^{1}$ The artist has included those characters essential to understanding the lived reality of this epidemic: the victims of plague, the body clearers, the beleaguered residents desperate for a return to order within a city made alien and threatening, and the holy figures who, as sacred intercessors, were felt to be critical to the city's salvation. This article seeks to position Zanchi's painting within postepidemic Venice, to consider not merely its importance to the confraternity of San Rocco, responsible for its commission, but to interrogate it within the broader cultural context of mid-seicento Venice. The 1630-31 plague, in fact, erupted in the midst of a vibrant period in the visual and performance arts in

\footnotetext{
${ }^{1}$ For information on the 1630-31 plague epidemic in northern Italy, see Venezia e la peste: 1348-1797 (Venice: Marsilio), 1979, particularly the essay by Paolo Preto, 'Le grandi pesti dell'età moderna: 1575-77 and 1630-31', 123-56. See also Paolo Ulvioni, Il gran castigo di Dio: Carestia ed epidemie a Venezia e nella Terrafirma, 1628-1632 (Milan: Franco Angeli Libri), 1989; and Richard Palmer, The Control of Plague in Venice and Northern Italy, 1348-1600, PhD dissertation, University of Kent at Canterbury, 1978.
} 


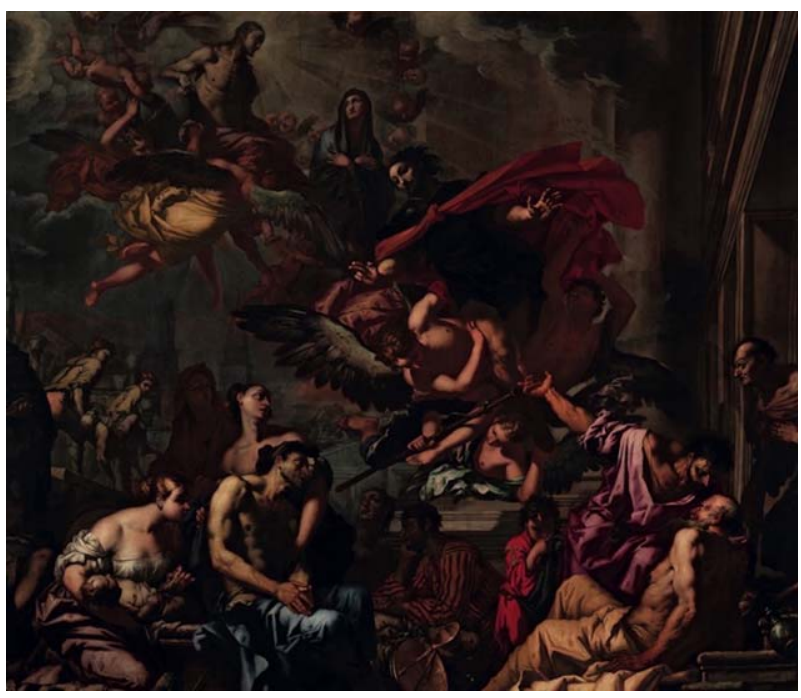

Fig. 4 'The Virgin Appears to the Plague-Stricken', detail (photo: Scuola Grande di San Rocco)

Venice, marked by dynamic spectator involvement, artful staging, and a celebratory mythologizing of Venetian history and politics.

Antonio Zanchi's painting was commissioned not during the epidemic, but thirty-five years after the end of the crisis, in 1666. The guardian grande of the Scuola di San Rocco, head of the city's preeminent confraternity dedicated to the popular plague saint Roch, paid for this work. Its completion date does not correspond with Venice's yearly celebration of deliverance from plague on November 21, nor any other dates significant to previous plague epidemics, and thus raises the question of why this painting was created. One should consider what was at stake for the Scuola di San Rocco in 1666, and what the organization hoped to achieve with the display of this evocative painting.

As the premier social institution that served as custodian of the cult of Saint Roch - his body was interred in their confraternal church - the Scuola Grande di San Rocco provided charitable relief in the city and honoured the plague saint through processions, feasts, and the embellishment of their opulent meetinghouse. ${ }^{2}$ The Scuola commissioned Zanchi's painting when the most visible and elaborate memorial to the 1630-31 plague, the State-sponsored Santa

\footnotetext{
${ }^{2}$ For early modern criticism on the construction of the stairwell, the costs for which were construed as a misuse of charitable funds, see the 1541 satirical poem by Alessandro Caravia, Il Sogno dil Caravia (Venice: G. A. di Nicolini da Sabbio). Brian Pullan and Philip Sohm have each examined the controversy. Pullan, 'Pomp and Office: the Citizens and the Scuole Grandi', in Rich and Poor in Renaissance Venice: the Social Institutions of a Catholic State to 1620 (Oxford: Blackwell, 1971), 99-131, and Philip Sohm, 'The Staircases of the Venetian Scuole Grandi and Mauro Coducci', Architectura, 8 (1978), 125-49.
} 


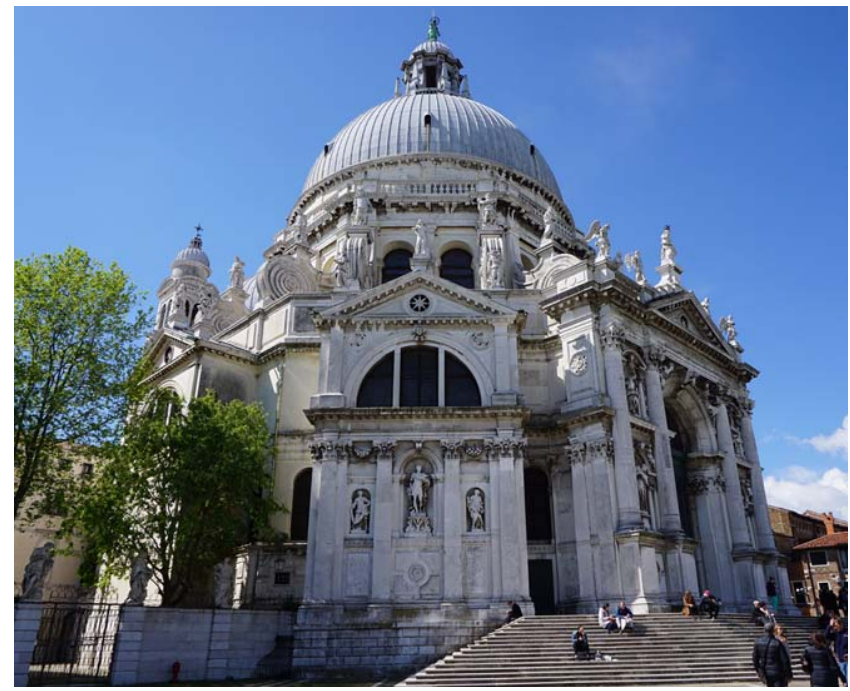

Fig. 5 Baldassare Longhena, 'Santa Maria della Salute', consecrated 1687 (photo: author)

Maria della Salute, was nearing completion (Fig. 5). ${ }^{3}$ The cornerstone of Baldassare Longhena's votive church was laid during the epidemic on 1 April 1631 , and construction continued thereafter. During the 1660s, the main dome and the two towers were completed, while the six altars that ring the central space inside were decorated with paintings and sculptures reflecting the Marian dedication of the church. ${ }^{4}$ It was at this time that the Scuola di San Rocco hired Antonio Zanchi to adorn their grand stairway, resulting in a work whose large scale and triumphant tone represented the confraternity's continued relevancy as protector of the city's spiritual and bodily health. This commission perhaps originated in a spirit of competition, but certainly in a desire to exploit the commemorative moment engineered by the Senate. ${ }^{5}$ The unveiling of Zanchi's extravagant plague painting directed attention to the confraternity's meetinghouse and to the site of the plague saint's cult, making visible the Scuola's role in securing holy intercession during epidemics.

The painting is a tour de force. Through the monumental size and provocative imagery of the work, the artist sought to elicit strong emotive responses in viewers, amplified by his effective use of the built environment of the stairway. The visual rhetoric of this painting, rather than being constrained by the expedient label of 'Baroque style', should be understood within the broader context of artistic developments across the arts in seicento Venice. Venetian painting in

\footnotetext{
${ }^{3}$ For more on the Salute commission, see Andrew Hopkins, Santa Maria della Salute: Architecture and Ceremony in Baroque Venice (Cambridge: Cambridge University Press), 2000.

${ }^{4}$ Hopkins, 69-75.

${ }^{5}$ On the role of competition in generating large-scale building campaigns and commissions in Venice, see Patricia Fortini Brown, 'Honor and Necessity: the Dynamics of Patronage in the Confraternities of Renaissance Venice', in Studi Veneziani XIV (Pisa: Giardini, 1987), 179-212.
} 
this period has not garnered as much scholarly attention as that in the previous two centuries. This relative paucity of scholarship can be attributed in part to a supposed gap in artistic production that opened between the deaths of the three masters, Titian, Veronese, and Tintoretto, at the end of the sixteenth century, and the rise of the internationally popular Giambattista Tiepolo in the eighteenth. ${ }^{6}$ The perception of a lull in elite artistic production from 1600 to 1700 has been magnified by the thesis of Tiepolo's revivification of Venetian splendor in the midst of decadence and decline as the Republic edged into political irrelevancy in the decades leading up to the city's fall in 1797. This conventional periodization of Venetian art fails to acknowledge the continued vitality of the region's art market throughout the seventeenth century, as well as significant new developments in visual culture. ${ }^{7}$ Seicento plague art in Venice is one of these areas of innovation. ${ }^{8}$

Chiara Ceschi, in the definitive, two-volume study on the art and architecture of the Scuola Grande di San Rocco's meetinghouse, published in 2008, described Zanchi's painting with respect to its tenebristic shadows and bodies rendered in stylized poses as the 'perfetta macchina teatrale barocca' ${ }^{9}$ Building on this characterization, and informed by the rich culture of plague memorialization, I will pursue the question of what theatricality and staging might have meant in Venice during the 1660s. Spectatorship and the notion of an embodied viewer were defining conceits driving Zanchi's work for the confraternity. In this article, I will demonstrate how the artist's experience producing materials for opera performances early in his career informed his transformation of the Scuola's stairwell into a dramatic environment activated by viewers ascending and descending through the space. The devices used by the painter to achieve this effect, however, originate outside of opera and can be situated within the broader tradition of Venetian painting practices, characterized by dynamic compositions and the visualization of spectacle in the city.

\footnotetext{
${ }^{6}$ The first mention of these painters as a Venetian 'triumvirate' appears in 1674, in Luigi Scaramuccia's $L e$ finezze de' pennelli (Pavia: per Gio. Andrea Magri). In modern scholarship, see David Rosand, Painting in Cinquecento Venice: Titian, Veronese, Tintoretto (New Haven: Yale University Press), 1982; Vittoria Romani, Tiziano e il tardo rinascimento a Venezia: Jacopo Bassano, Jacopo Tintoretto, Paolo Veronese (Milan: Il Sole 24 ore), 2007; Titian, Tintoretto, Veronese: Rivals in Renaissance Venice, ed. Frederick Ilchman (Boston: MFA Publications), 2009. Important scholarship on Giambattista Tiepolo includes Massimo Gemin, Giambattista Tiepolo: $i$ dipinti, opera completa (Venice: Arsenale editrice), 1993; and Keith Christiansen, ed. Giambattista Tiepolo: 1696-1770, ex. cat. (New York: Metropolitan Museum of Art), 1996.

7 Taryn Zarrillo's recent dissertation seeks to recuperate seventeenth-century Venetian art. See Artistic Patrimony and Cultural Politics in Early Seicento Venice, PhD dissertation, Columbia University, 2016.

${ }^{8}$ The most influential publication on plague art in Venice remains the 1979 exhibition catalogue Venezia $e$ la peste. Stefania Mason and Louise Marshall have made substantial contributions to the topic in recent years. See Stefania Mason, 'L'immaginario della morte e della peste nella pittura del Seicento', in La pittura nel Veneto. Il Seicento (Milan: Electa, 2000), 523-42; and Louise Marshall, 'A Plague Saint for Venice: Tintoretto at the Chiesa di San Rocco', Artibus et Historiae, 66 (2012), 153-88. For scholarship on Antonio Zanchi's career, see Alberto Riccoboni, 'Antonio Zanchi e la pittura veneziana del seicento', Saggi e memorie di storia dell'arte, 5 (1966), 53-135; and Beatrice Andreose and Felice Gambarin, Antonio Zanchi, 'Pittor Celeberrimo' (Vicenza: Terra Ferma), 2009.

${ }^{9}$ Franco Posocco (ed.) La Scuola Grande di San Rocco a Venezia (Modena: Panini, 2008), 236-7.
} 
Conceptually, as well as formally, The Virgin Appears to the Plague-Stricken was influenced by the combination of emergent theatrical performances in Venice and established traditions in civic art production.

\section{ADORNING THE GRAND STAIRWAY OF THE SCUOLA GRANDE DI SAN ROCCO}

An inscription located on the bridge depicted in Zanchi's painting, to the immediate left of the pilaster, notes that the work was dedicated on 14 October 1666 to the Virgin and Saint Roch by the Guardian Grande of the Scuola Grande di San Rocco, Bernardo Briolo. ${ }^{10}$ Unfortunately, information related to the painting's commission, such as its cost and any stipulations made by the confraternity, has not been found in the Scuola's archives. ${ }^{11}$ Because of the Senate's scrutiny of the immense expenses paid by scuole grandi in the seventeenth century to embellish their meetinghouses - potential misuses of charitable funds - the funding of works of art to adorn these sites was more carefully managed than in the past, and also more difficult to track. ${ }^{12}$ Guardian grandi, the elected heads of these confraternities, served one-year terms and were expected to leave a lasting mark during their tenures by hosting lavish banquets and concerts of sacred music, and commissioning paintings, sculptures, and other precious objects that would further distinguish the institution. Most important, they were expected to pay for these extravagances themselves. ${ }^{13}$ Guardian Grande Bernardo Briolo, in keeping with this seicento convention, most likely paid for Antonio Zanchi's painting with his own funds, and any receipts or other related documents would have been kept within his personal files. ${ }^{14}$ Despite his footing the bill, the subject matter and intellectual content of Antonio Zanchi's painting would not reflect the guardian's personal tastes, so much as the Scuola's institutional ideology and self-promotion. Because it was a major work of art adorning a highly visible and ceremonial space in the

10 'DOM / DEIPARAE VIRGINI DIVOQ. ROCHO / HANC DICAVIT PICTURAM / BARNADUS BRIOLUS / GUARDIAN.S MAIOR / ANNO D.NI MDCLXVI / DI XIV MENSIS OCTOB. / ANT.S ZANCHI P.P.' Bernardo Briolo, Guardian Grande, dedicates this painting to the Virgin, mother of God, and to Saint Roch, in the year of our Lord 1666, October 14. Antonio Zanchi, painter, painted this.

11 Neither the guardian's files nor the receipt books recording monies paid for building maintenance yield any information on this painting. The guardian grande's files for the relevant years are: Archivio di Stato di Venezia (hereafter ASV), Scuola Grande di San Rocco, seconda consegna, cauzione, reg. 186, filza n.33 (1665-6), and for the pendant to Zanchi's work across the stairwell, Pietro Negri's The Madonna Saves Venice from the Plague of 1630, ASV, SGSR, seconda consegna, cauzione, reg. 189, filza n.35 (1672-3). Receipt books for relevant years: ASV, SGSR, seconda consegna, ricevute, reg. 424.

12 Pullan, Rich and Poor in Renaissance Venice, 99-131. For more on the construction of the stairway, see Gianmario Guidarelli, 'La fabbrica della Scuola Grande di San Rocco', in La Scuola Grande di San Rocco a Venezia, 43-63.

13 The costs necessary to fund a one-year term as guardian grande of the Venetian scuole grandi were prohibitive. See Pullan, 122. ASV, Consiglio dei Dieci, registro commune 1605, fols. 27v-38v.

${ }^{14}$ My scrutiny of the Scuola's files from this era did not uncover any documents known as rodoli related to Zanchi's work. Rodoli were fund-raising contracts circulated amongst the confratelli that would help guardians fund large-scale projects through the collection of donations from brothers. For more on the use of rodoli in the scuole grande during the seventeenth century, see Jonathan Glixon, Honoring God and the City: Music at the Venetian Confraternities, 1260-1807 (Oxford: Oxford University Press, 2003), 27. 


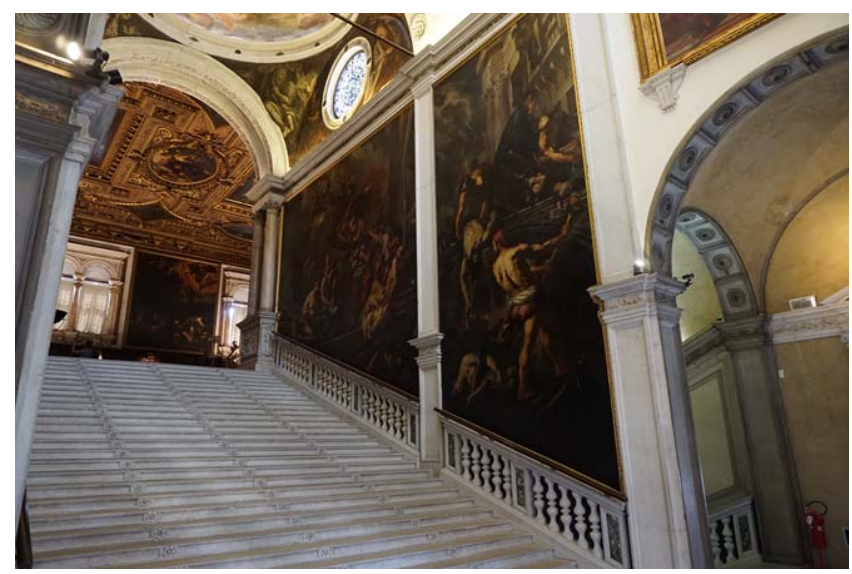

Fig. 6 Grand stairway of the Scuola Grande di San Rocco (photo: author)

San Rocco meetinghouse, the governing bodies of the confraternity (specifically the highest-ranking brothers advising the guardian known as the banca), would have decided upon the content of this commission. The subject matter represents the corporate identity of the institution and its role as custodian of the body and cult of the most important plague saint in Venice.

Zanchi's painting is located on the southwest wall of the grand staircase that connects the confraternity's ground floor to its vast upper hall (Figs. 6 and 7), decorated in the sixteenth century with Tintoretto's famed paintings. The work activates a threshold space, through which confratelli and visitors moved constantly. Zanchi's painting has a pendant across the stairwell, The Madonna Saves Venice from the Plague of 1630, completed by Pietro Negri in 1673 (Fig. 8). ${ }^{15}$ Antonio Zanchi's painting, completed seven years prior to Negri's, determined the conceit and tone that Negri was later to adopt in order to create a harmonious pairing on the stairway. Though both works reflect the same commemorative impulse by the Scuola, their emphases are different. Negri's composition, while complimentary to Zanchi's in style and content, focuses more on the spiritual path of intercession, using a language of allegory and symbol not found in Zanchi's work. Negri's painting also lacks the visceral punch offered by its companion across the stairwell, retreating into metaphors more easily palatable than Zanchi's overt shock-aesthetic. However, both works create tableaux resembling the stage settings of theatrical productions in seicento Venice, particularly those used in public opera. An investigation of Zanchi's work for the Scuola will show that the artist sought, through a variety of pictorial strategies,

\footnotetext{
${ }^{15}$ Negri's commission for San Rocco appears in period criticism in Boschini, Le ricche minere della pittura veneziana (Venice: Francesco Nicolini, 1674), 51-2; Zanetti, Descrizione di tutte le pubbliche pitture della città di Venezia e isole circonvicine (1733), 303; Zanetti, Della pittura veneziana (1771), 406-7. For modern scholarship, see Posocco, La Scuola Grande di San Rocco a Venezia, 237; Venezia e la peste, 276-7; Mason (2001), 540-1; Alberto Craievich, 'Un modelletto di Pietro Negri', Arte in Friuli, Arte a Trieste, XXIV (2005), 21-5.
} 


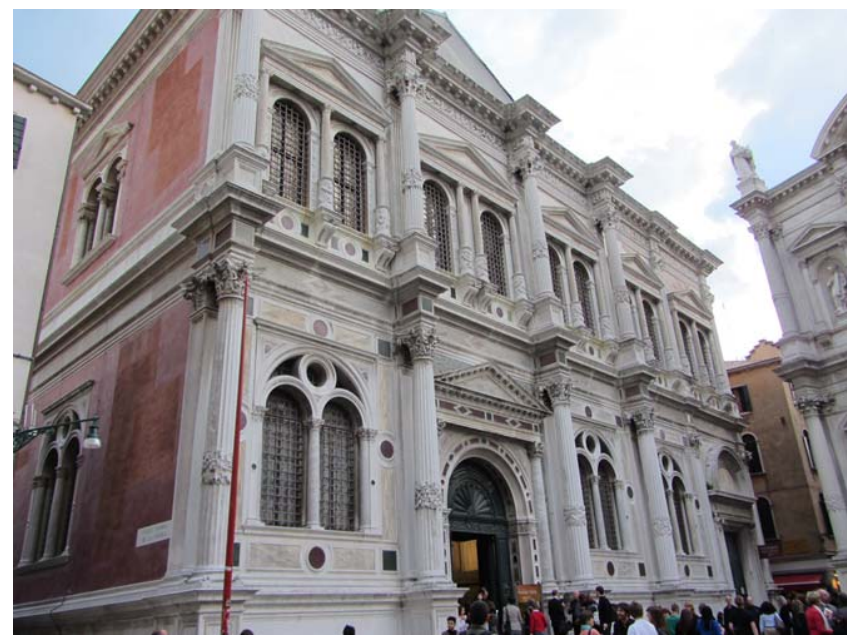

Fig. 7 Façade of the Scuola Grande di San Rocco (photo: author)

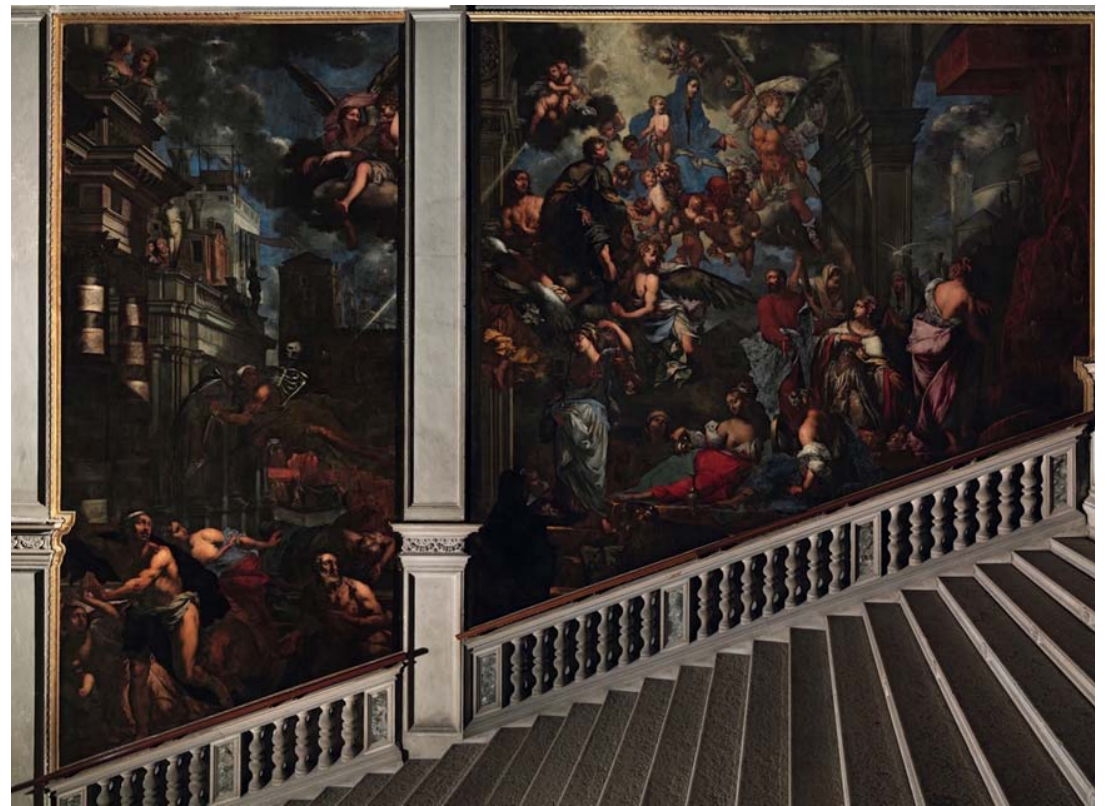

Fig. 8 Pietro Negri, 'The Madonna Saves Venice from the Plague of 1630', 1673, oil on canvas (two canvases separated by a pilaster), $335 \times 555 \mathrm{~cm}$ and $635 \times 705 \mathrm{~cm}$, Scuola Grande di San Rocco, Venice (photo: Scuola Grande di San Rocco)

to create a work that would engage and thrill spectators in a manner evocative of experiencing live theatrical performance. In my analysis of Zanchi's painting, I have privileged movement upwards on the stairway for an important 
reason: both paintings were designed to be experienced by viewers oriented on the right side of the stairs. Holy intercessors look down to viewers at the bottom of the steps in Zanchi's painting, and they gaze upwards in Negri's painting, making eye contact with those descending the stairs to the right. Narrative progression in each work advances from this orientation.

\section{EXPERIENCING PLAGUE IN SEICENTO VENICE}

The dark tonality of Zanchi's The Virgin Appears to the Plague-Stricken has been referred to as 'tenebristic' since the seventeenth century, an effect somewhat different from Tintoretto's more moderate chiaroscuro. ${ }^{16}$ The painting first appears in printed commentary in Marco Boschini's Le ricche minere della pittura veneziana of 1674 . Boschini praised the artist for his masterful rendering of the varied emotions exhibited by the figures beneath the Virgin and Saint Roch, which he deems capable of evoking similar states of terror and pity in viewers: ${ }^{17}$ 'In aria, poi si vede la B. V. Maria e San Rocco intercessori, genuflessi appresso la Divina Maestà, pregando per il sollievo di quel flagello: espressioni in ogni genere così raramente rappresentate, che in un 'istesso rendono terrore, e pietà. ${ }^{, 18}$ Writing a century later in 1771, Antonio Maria Zanetti declared this painting to be the best of Zanchi's oeuvre, invoking in particular the artist's ability to create drama from the juxtaposition of mid-tones with deep shadows, awing viewers with the resulting force of his compositions: '. . .dando rilievo alle figure sue con il mezzo d'ombre gagliarde e masse grandi di scuro. ${ }^{19}$ Indeed, the painting's idiosyncratic highlights and shadows - which do not appear to correspond with a particular light source within the painting or to the location of windows in the Scuola's stairwell - were designed to obscure portions of the canvas until viewers entered into close proximity with each depicted episode. Light breaks through the clouds in the upper left corner of the canvas in the celestial apparition of Christ and the Virgin, but these rays do not illuminate the full composition. The marked contrast in lighting that gives prominence to the colossal bodies in the foreground appears to originate from outside the canvas, from the stairway setting where viewers stand. The effect conjures the diffuse but locally concentrated lighting used in seicento operas and other theatrical productions, in which sets and

\footnotetext{
${ }^{16}$ On Zanchi's role as a tenebrist, see Bernard Aikema, 'Il secolo dei contrasti: le tenebre', in La pittura nel Veneto: Il Seicento (Milan: Electa, 2000), 543-72.

17 Boschini, Le ricche minere (1674), 'Sestier di San Polo', 51.

18 Ibid.

19 Zanetti, Della pittura veneziana e delle opere pubbliche de veneziani maestri, libri V (Venice: G. Albrizzi, 1771), 404-5. 'Questo nuovo stile che lunge da Venezia ebbe i principii suoi, vantava sopra tutto perfetta imitazione del naturale, qualunque l'avesse ritrovato il Pittore, e volea sorprendere lo spettatore con aspra violenza, senza curarsi d'allettarlo...Era dunque pertanto buon naturalista, rappresentando la morbidezza e gli effetti della carne con intelligenza e facilità; dando rilievo alle figure sue con il mezzo d'ombre gagliarde e masse grandi di scuro.'
} 


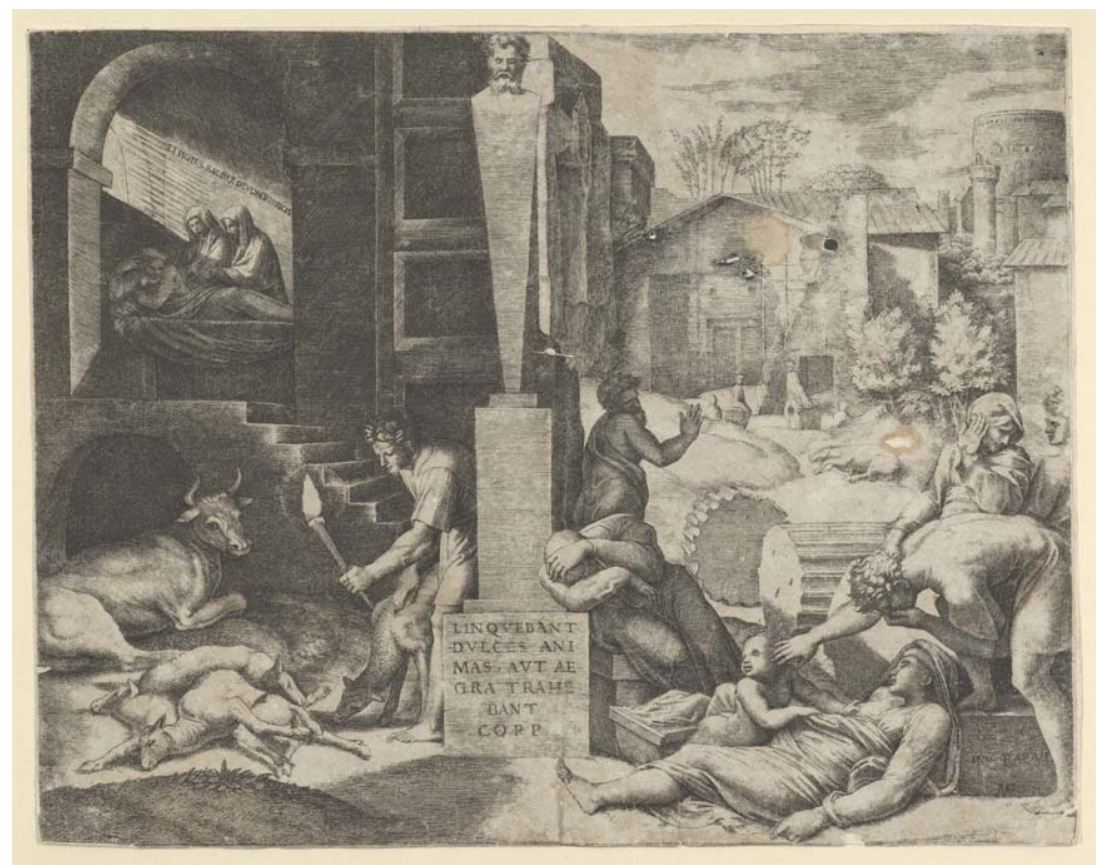

Fig. 9 Marcantonio Raimondi, 'Il morbetto', c.1515, engraving, $19.5 \times 25 \mathrm{~cm}$ (photo: Metropolitan Museum of Art, New York)

performers were illuminated by vast numbers of candles and oil lamps located behind frames, from free-standing supports, and as footlights. ${ }^{20}$

The painting taps into a rich tradition of plague imagery that had evolved following the first appearance of this disease in Western Europe during the plague pandemic that began in 1347. Jaundiced clouds stack up and cut diagonally through the sky of Venice, obscuring the city's architecture like the poisonous air of plague. In addition to the miasma theory of disease transmission, commonly alluded to in plague imagery, Zanchi depicted a number of other tropes that had become visual shorthand for plague by this time. These include a topographical rendering of the city that locates the narrative action and speaks to the desire for civic order during crises; the appearance of holy intercessors within a bank of clouds, also ubiquitous amongst painted ex-votos that seek relief from a variety of misfortunes and ailments; and the poignant pairing of a mother stricken by disease and her child, which was first disseminated in 1515 through a print representing plague in classical antiquity by Marcantonio Raimondi, after Raphael's

\footnotetext{
${ }^{20}$ On theatrical lighting in the period, see Per Bjurström, 'Giacomo Torelli and Baroque Stage Design', in Figura (Stockholm: Alqvist and Wiksell, 1961), 56.
} 


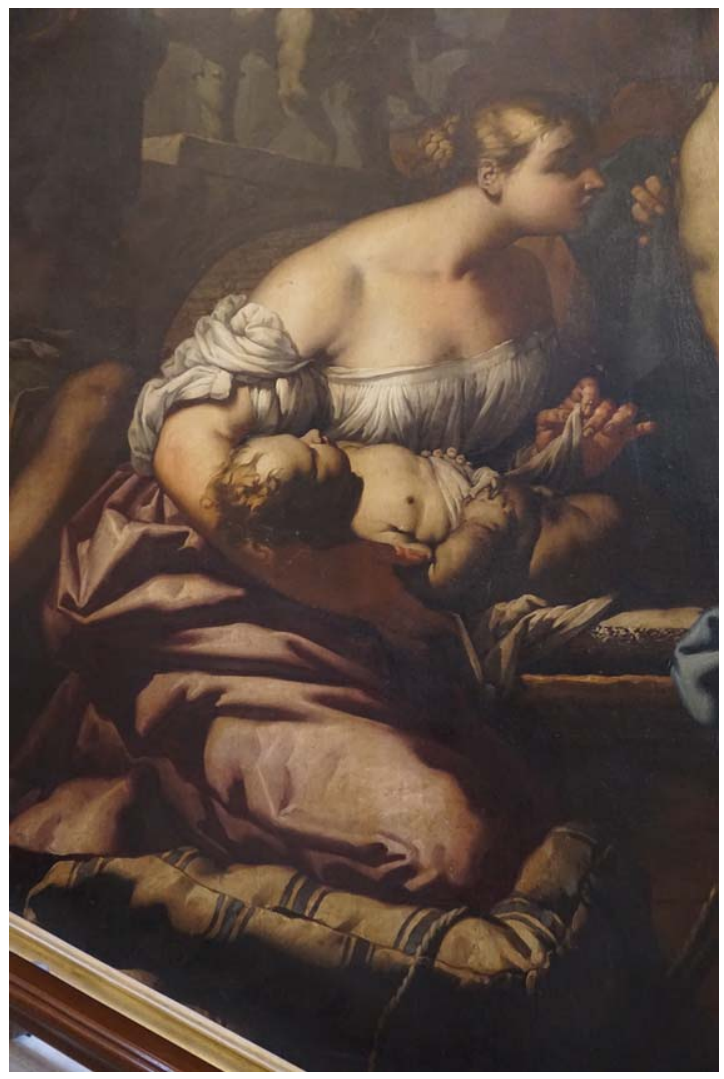

Fig. 10 'The Virgin Appears to the Plague-Stricken', detail (photo: author)

design (Fig. 9). ${ }^{21}$ Cleverly, Zanchi included two prominent pairs of mothers and babies, as binary opposites. The first mother and child viewers encounter on the stairs, as noted above, are stiffened corpses. The second pair appears further up the stairs, alive and directly beneath Christ, suggesting that through proper veneration and an appeal to sacred intercessors, salvation from plague is possible (Fig. 10).

As a prominent work of art ornamenting the meetinghouse of Venice's wealthiest confraternity, the painting had to be appropriately opulent, and it needed to emphasize the Scuola's role in holy intercession. Though Christ appears as the ultimate source of salvation in this painting, Zanchi depicts a chain of transmission through which Saint Roch, held aloft in the middle ground by a trio of angels, is positioned in the composition as the first to hear

${ }^{21}$ For an examination of the development and evolution of plague imagery in Venice, see Jennifer Gear, Visualizing the 1630-31 Plague Epidemic in Early Modern Venice and the Veneto, PhD dissertation, University of Michigan, 2018. 
the prayers of devotees. He serves as an intermediary who advocates for them to the Virgin, who then appeals to Christ. The message is clear: in seeking deliverance from plague, San Rocco forms a critical link between the horrors on earth and God's benevolence.

In visualizing the recent plague epidemic, Zanchi has constructed a narrative order for the crisis that situates it within Venice's history. Plague erupted frequently throughout the Italian peninsula from its first appearance in the midfourteenth century through the seventeenth century. The fifteenth century in particular witnessed a number of relatively mild but near constant outbreaks of plague in this region. ${ }^{22}$ However, the nature of the disease shifted in the midsixteenth century, and plague outbreaks became fewer in number but more severe in intensity. The worst plague epidemics to have affected Venice were those of 1575-77 and 1630-31, each of which killed roughly 50,000 people. ${ }^{23}$ While plague continued to spring up in Western Europe until the middle of the eighteenth century, the last outbreak to strike Venice was that of 1630-31. ${ }^{24}$

The narrative structure of Zanchi's painting was conceived with reference to the sophisticated policies for quarantine and disinfection imposed by the Venetian State during the two major plague epidemics of the sixteenth and seventeenth centuries. Zanchi highlighted one of the most compelling characters that signified the 1630-31 epidemic in particular: the body clearers tasked with maintaining city sanitation. Documents from 1630 reveal the concerns of the city Health Office (Sanita) for controlling the proliferation of plague victims' corpses, major sources of contagion and ghastly reminders of the dire circumstances in the city. During the 1575-77 epidemic, one hundred body clearers pizzigamorti - had been employed. ${ }^{25}$ Their job entailed the crucial tasks of removing bodies for burial from homes, streets, and the city's two plague hospitals (lazzaretti), and escorting confirmed and suspected cases to quarantine. Documents disclose that the pizzigamorti were over-burdened. Bodies piled up, remaining unburied or unburned, and at times the ill were shuffled into boats filled with corpses intended only for transporting the dead, as there were not enough body clearers to man additional boats. ${ }^{26}$ To avoid repeating these

\footnotetext{
22 Richard Palmer, The Control of Plague, 27-50; Samuel K. Cohn, Cultures of Plague: Medical Thinking at the End of the Renaissance (Oxford: Oxford University Press), 2010; Ann Carmichael, 'Plague Legislation in the Italian Renaissance', Bulletin of the History of Medicine, 57 (1983), 508-25.

${ }^{23}$ Reinhold C. Mueller, 'Peste e demografia: medioevo e rinascimento', in Venezia e la peste, 93; Ulvioni, 73.

${ }^{24}$ Richard Palmer posits that Venice expelled plague from its central urban cluster and kept it at bay through the widespread efforts of its Health Office, though there is still no consensus amongst medical historians as to why plague disappeared from Europe. See Control of Plague, 315-21.

25 ASV, Secreta Materia Miste Notabile 95, 66v, 9 August 1576; ASV, Sanità reg. 17, 223r, 19 December 1630. See also, Biblioteca Museo Correr (hereafter BMC), Codice Cicogna, 1509. Published in Jane Crawshaw, 'The Beasts of Burial: Pizzigamorti and Public Health for the Plague in Early Modern Venice', Social History of Medicine, 24 (2011) , 573, n22; and Jane Crawshaw, Plague Hospitals: Public Health for the City in Early Modern Venice, (Farnham, Surrey: Ashgate, 2012), 197, n61. See also Venezia e la peste, 143.

${ }^{26}$ This anecdote appears in the account of a notary living in the city. Rocco Benedetti, Relatione d'alcuni casi occorsi in Venetia al tempo della peste l'anno 1576 et 1577 con le provisioni, rimedii et orationi fatte à Dio Benedetti pe la sua liberatione (Bologna, 1630), 22. Cited in Crawshaw, Plague Hospitals, 89, n55, and Venezia e la peste, 127.
} 


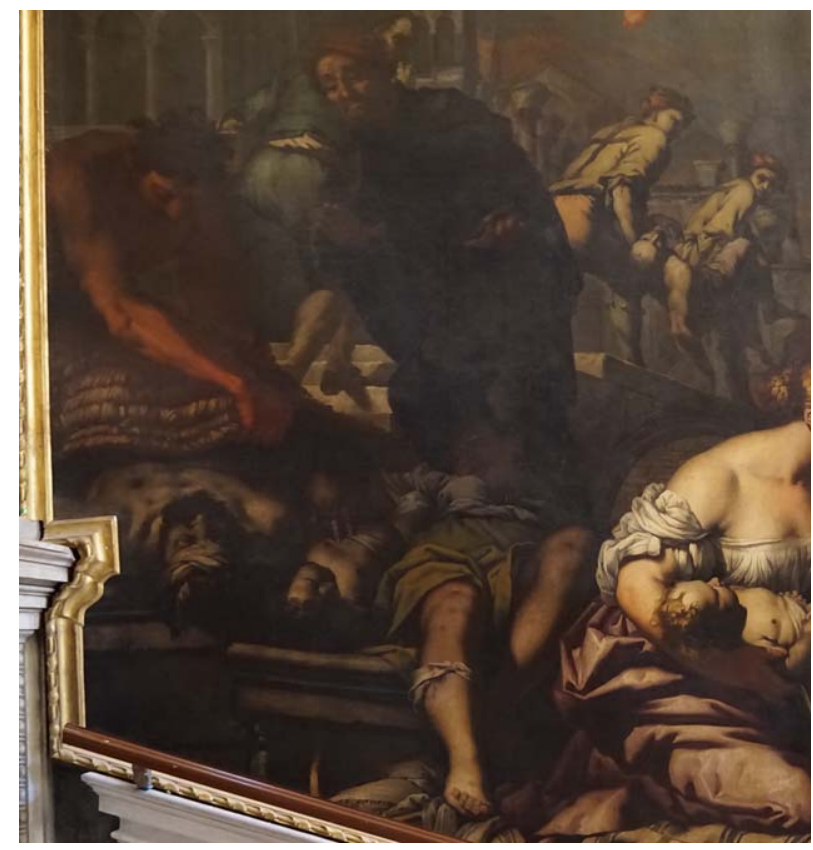

Fig. 11 detail of pizzigamorti (photo: author)

unfortunate episodes, the Sanita tripled the number of pizzigamorti employed in 1630 , and the city was filled with these men - feared for their proximity to infectious materials and bodies and their movement across quarantine lines in the city. ${ }^{27}$ Stories emerge of Venetians dying of fright upon hearing the creak of their carts' wheels and the jingle of the bells tied around their calves, or succumbing upon seeing their black boats bobbing in the lagoon. ${ }^{28}$ Jane Crawshaw's recent work on the pizzigamorti has traced the evolution of metaphors used to describe these body clearers, who were characterized as wild animals beasts, roaming the city, without compassion or respect for order. ${ }^{29}$

The pizzigamorti swarm in Zanchi's painting. No fewer than nine of them appear in the composition, an infestation in themselves, immediately discernable by the tasks they perform. They appear as sharply-lit characters in the

\footnotetext{
27 Venetians had another reason to fear the pizzigamorti in 1630-31. Per the Senate's efforts to increase the number of body clearers in the city, men to fill these positions were sought amongst prisoners, who were guaranteed cleared criminal records if they served as sanitation workers. ASV, Senato Terra Registro, 104, 15 November 1630, and 3 and 18 December 1630. Cited in Venezia e la peste, 143.

28 For work on fear in early modern Italy as a dangerous condition, capable of hastening death in the weak, and even striking down the healthy in acute attacks, see David Gentilcore, 'The Fear of Disease and the Disease of Fear', in Fear in Early Modern Society, eds. William Naphy and Penny Roberts (Manchester: Manchester University Press, 1997), 184-208; Samuel Cohn, Cultures of Plague, 'Plague Psychology', 264-93; and Sheila Barker, 'Poussin, Plague, and Early Modern Medicine', Art Bulletin, 86 (December 2004), 659-89.

29 Crawshaw's article, 'Beasts of Burden', addresses the issue of pizzigamorti directly, though her subsequent book on the lazzaretti, Plague Hospitals, provides a sustained look at these sanitation workers.
} 


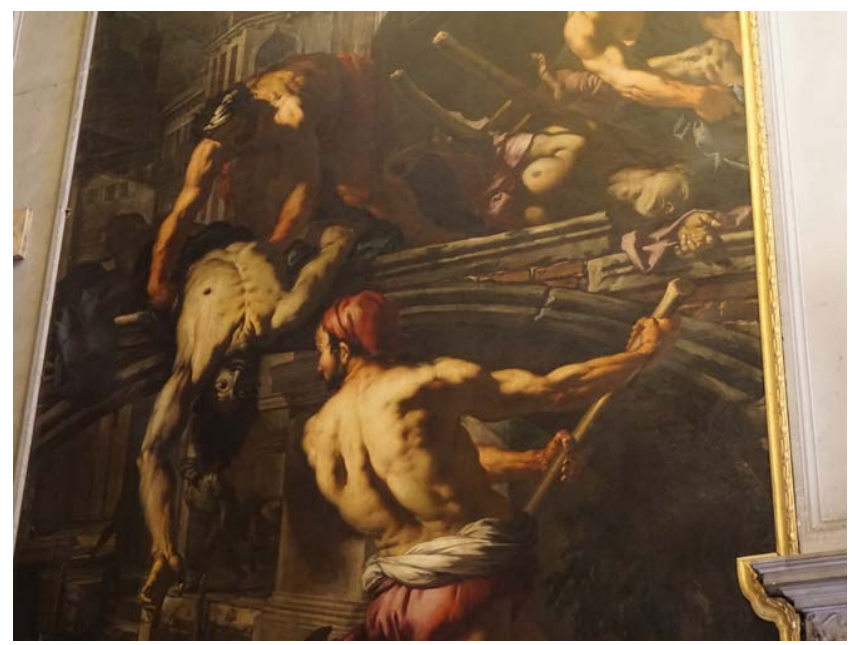

Fig. 12 detail of corpse and pizzigamorto (photo: author)

foreground at the bottom right, in the painting's most dramatic zone at the bottom of the stairway. Pizzigamorti are also visible in the background, as tiny figures hauling stretchers and as workers strangely covering plague victims with a kind of large basket shown elsewhere in the painting holding food (Fig. 11). Some pizzigamorti wear the distinguishing garments described in early modern texts: crosses on their backs and bells at their calves. ${ }^{30}$ However, the body clearers singled out by Zanchi as most important - those first confronting viewers on their progress up the stairs - appear in a state of near dishabille (Fig. 12). Their nudity provided an opportunity for the artist to showcase his mastery of the male body, a nod to the work of Michelangelo and Tintoretto. The pizzigamorti's undress also underscores the nature of their physically punishing job and the animal metaphors with which they were described. However, I would contend that Zanchi has also used these figures to create one of the most affective passages in the composition. The pizzigamorto who steers the boat containing the dead woman and her child is turned away from viewers, his face obscured, but for a sliver of profile. He stares into the face of the corpse slung over the side of the bridge, dangling upside down. These two men's faces - the living and the dead - meet in the open air beneath the bridge as an inverted mirror image. The body clearer seems to pause in his work to stare at the face before him in a remarkable memento mori. His expression is one of introspection and empathy, characteristics not found in the bestial descriptions of these men. While Zanchi created an unsettling composition by filling it with these fraught figures who emblematized fear and inhumanity, he also used these same men to convey a

\footnotetext{
${ }^{30}$ William G. Naphy, Plagues, Poisons, and Potions: Plague-Spreading Conspiracies in the Western Alps, c.15301640 (New York: Palgrave, 2002), 115; Crawshaw, Plague Hospitals, 131. Pizzigamorti removed bodies at night to reduce contact with living residents. ASV, Secreta MMN 95r, 5 October 1576.
} 
powerful emotive weight. In this passage, already provocative for the corpses whose empty eyes meet viewers entering the stairway, the figure of the pizzigamorto gazing into the face of the plague victim produces the subtlest meditation on mortality in the work.

While the stairwell provided the painter with a vast space in which to situate his canvas, the location also presented several challenges. Size itself placed particular demands on the artist, as did the trapezoidal shape, the relative narrowness necessitating a close viewpoint and sequential viewing, and the pilaster bisecting the wall and colonnade extending the length of the stairs. Zanchi embraced these challenges, turning the constraints imposed by the architecture to the expressive advantage of his work. Through the act of progressing up the stairs, viewers become actors in episodic scenes (Fig. 13). When ascending, visitors enter the stairwell at the bottom of the steps and find themselves standing within the water of the contaminated canals of 1630-31 Venice. This section of the painting is particularly dark, and the scene within reveals itself to viewers only as they enter into close proximity with it. The artist has placed the viewer effectively within the boat of infected bodies, beneath the corpse sliding down from the bridge above. Progressing up the stairs leads viewers to urban sites of decreasing contamination and toward holy intercession. The pilaster in the staircase wall has been adroitly incorporated as the outward face of a series of piers that extends into the deep representational space of the painting. The dado, in turn, reads as a railing that transforms the stairs into a virtual bridge running parallel to the depicted bridge in the painting. Through the work's responsiveness to the existing architecture, those who entered the Scuola's grand stairwell became participants in the plague of 1630-31, tacitly acting out their salvation by progressing away from a dangerous and polluted Venice and towards Saint Roch, the Virgin, and Christ.

\section{OPERATIC STAGING}

Antonio Zanchi's activation of the built environment and co-opting of spectators as participating actors developed out of several traditions of viewing and public spectacle in early modern Venice. In the mid-seventeenth century, when Zanchi and Negri completed their canvases for the Scuola, public opera was a new and popular form of entertainment in the city. The genre developed first in private court performances in Florence and Mantua, and in elite Roman circles - a melding of commedia dell'arte acting with humanist themes, innovated with passages of sung, rather than spoken, verse. ${ }^{31}$ In contrast to these private productions - closed events typically performed only once, to celebrate a particular political or social occasion - the fully developed operas that emerged in

\footnotetext{
${ }^{31}$ Ellen Rosand, Opera in Seventeenth-Century Venice: the Creation of a Genre (Berkeley and Los Angeles: University of California Press, 1991), 9-11.
} 


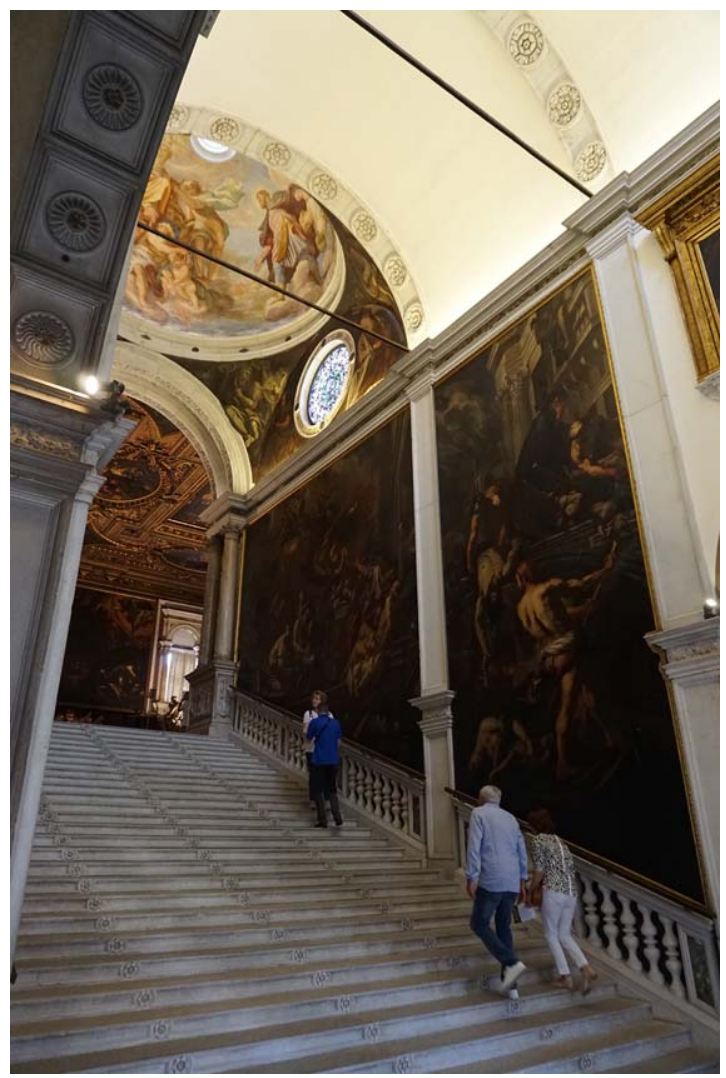

Fig. 13 Viewers as actors on the grand stairway (photo: author)

Venice in the 1640s were public affairs, paid for by private families and organized by hired impresarios.

Zanchi's The Virgin Appears to the Plague-Stricken exhibits several technical similarities to conventions used in stage set designs for seicento operas, as well as a shared interest in viewership and a mythologizing of current events in Venice. Though it is little remarked upon in scholarship today, Zanchi had a known professional connection with opera in Venice during the 1650s and 1660s. The artist produced a number of high quality engravings for frontispieces printed in libretti during this period (Fig. 14) ${ }^{32}$ Pietro Negri had some experience in this arena as well, having provided the frontispiece for a Venetian opera in

32 Bernard Aikema, Pietro della Vecchia and the Heritage of the Renaissance (Florence: Istituto Universitario Olandese de Storia dell'Arte, 1990), 84-5. Zanchi's frontispieces are included in the following libretti: La Statira (1655), Apollo e Dafne (1656), Il Medoro (1658), Artemisia (1656), Elena (1659), Pompeo Magno (1666), L'Argia (1669), and Il Genserico (1669). See also Beth Glixon and Jonathan Glixon, Inventing the Business of Opera: the Impresario and his World in Seventeenth-Century Venice (Oxford: Oxford University Press), 2006, 122, n67. 


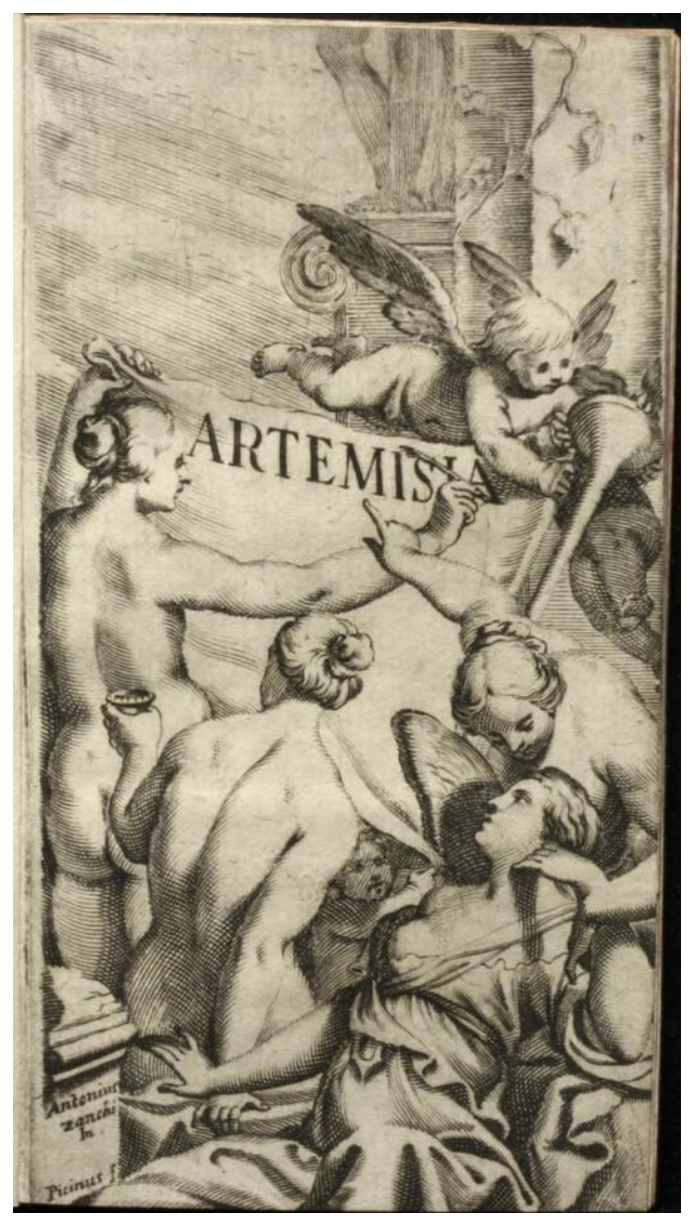

Fig. 14 Antonio Zanchi, frontispiece in libretto for 'Artemisia' (1656), performed at Teatro dei SS. Giovanni e Paolo, engraving, $14.7 \times 8.1 \mathrm{~cm}$, (photo: Biblioteca Estense Universitaria)

1658, though he was never as prolific as Zanchi, nor as entrenched within the circle of printers producing visual materials for libretti. ${ }^{33}$ More important than his reputation as a frontispiece engraver, Zanchi appears to have been involved in the production of scenery for opera performances as well. In the libretto for the 1656/57 performance of Le fortune di Rodope e Damira at the Sant'Aponal opera house, the artist is given credit for the stage settings. ${ }^{34}$ While Zanchi's

33 Aikema, 84-5. Negri provided the frontispiece for Antioco.

34 Aurelio Aureli, Le fortune di Rodope e Damira (Venice: Andrea Giuliani), 1657. See also Massimo Favilla and Ruggero Rugolo, 'Un tenebroso all'opera. Appunti su Antonio Zanchi', Venezia Arte 17/18 (2003-04), 62-3; Wendy Heller, 'Venezia in Egitto: Egyptomania and Exoticism in Seventeenth-Century Venice', in L'arte della scena e l'esotismo in età moderna, ed. Francesco Cotticelli and Paologiovanni Maione (Naples: Turchini Edizioni, 2007), 116; and Glixon and Glixon, 329. 


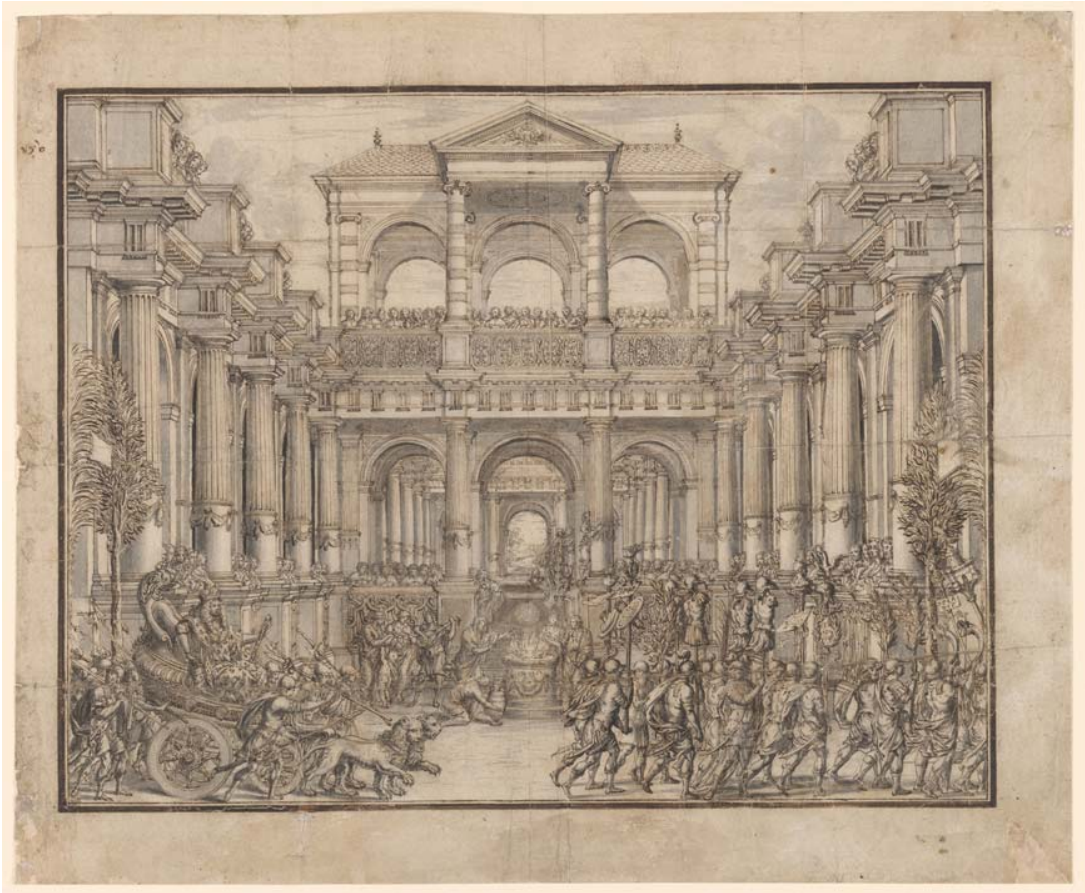

Fig. 15 Giacomo Torelli, 'Royal Entry into a Classical Court', mid-17th century, pen and ink, (photo: Morgan Library \& Museum, Gift of Mrs. Donald M. Oenslager, 1982, 1982.75:636; photography by Steven H. Crossot, 2014)

precise contributions to scenery-making remain unknown, is it clear that the painter knew through direct experience what was involved in the creation of large-scale flats and moveable staging elements. The artist was actively involved in producing a variety of materials for opera, both before and during his work at the Scuola Grande di San Rocco.

This involvement in opera set design influenced Zanchi's cultivation of a visual language built upon notions of spectacle and magnificence. His plague memorial for the Scuola Grande di San Rocco is an exercise in superabundance. The canvas presents an impression of hyperbolic fullness, from the shallow pictorial space that forces the over-life-size figures into the immediate foreground, to the exaggeratedly robust bodies, the straining sacks of contaminated food, and the piles of domestic items heaped at the canvas's lowest margins. In a way, Zanchi's painting illustrates an anti-magnificence: the splendors of a rich and abundant Venice gone rotten in the throes of an epidemic. This effect can be compared to a drawing entitled Royal Entry into a Classical Court by the scenographer and engineer Giacomo Torelli, which was created for the opera Les noces de Pelée et de Thétis performed in Paris in 1654, after Torelli left Venice for France (Fig. 15). The drawing represents an idealized vision of what 


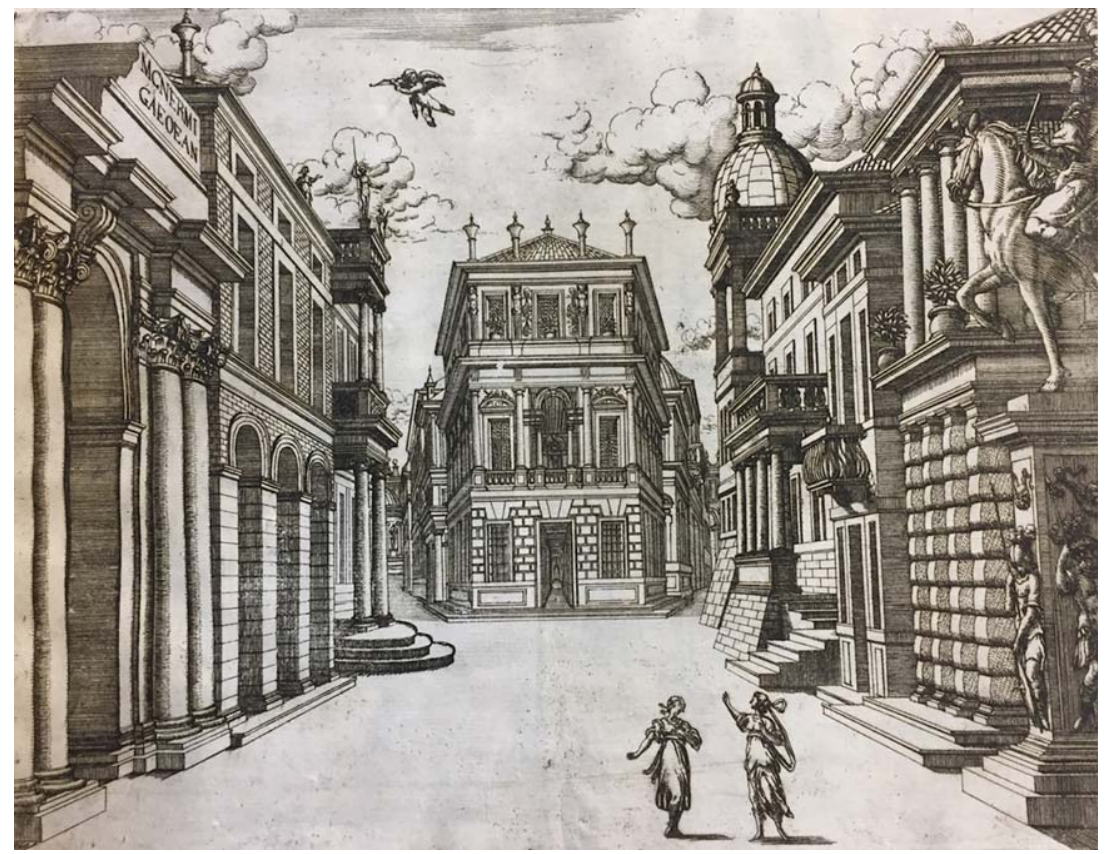

Fig. 16 Stage set for 'Venere gelosa', in 'Apparati scenici' (photo: author)

a successful opera production could achieve though a series of spectacles on stage, performed over consecutive acts. The main action occurs at the front of the stage with the entry of a king in elaborate costume, surrounded by scores of props and supporting actors. The architectural setting illustrates typical stage designs that evoked the deep space of a vanishing-point perspective through series of flats of diminishing size, paired with smaller, moveable elements. Illustrations of this spatial design strategy and descriptions of the magnificence of costumes used in actual performances can be found in a commemorative book published by Torelli in 1644 that features foldout engravings of sets from Bellerofonte, Venere gelosa, and Deidamia, as well as summaries of the narrative action and transcriptions of dialogue from these operas (Fig. 16).$^{35}$

A compositional device used by Torelli in his drawing Royal Entry, and repeated later by both Zanchi and Negri in their paintings for the Scuola, demonstrates the importance of spectatorship in seicento Venice, from practical and conceptual standpoints. At the top corners of Torelli's drawing, figures gaze down at the scene from niches in the architectural façades - virtual opera

\footnotetext{
35 Apparati scenici per lo Teatro Nouissimo di Venetia. Nell anno 1644 d'inuentione, e cura di Iacomo Torelli da Fano (Venice: Giovanni Vecellio e Matteo Leni), 1644.
} 


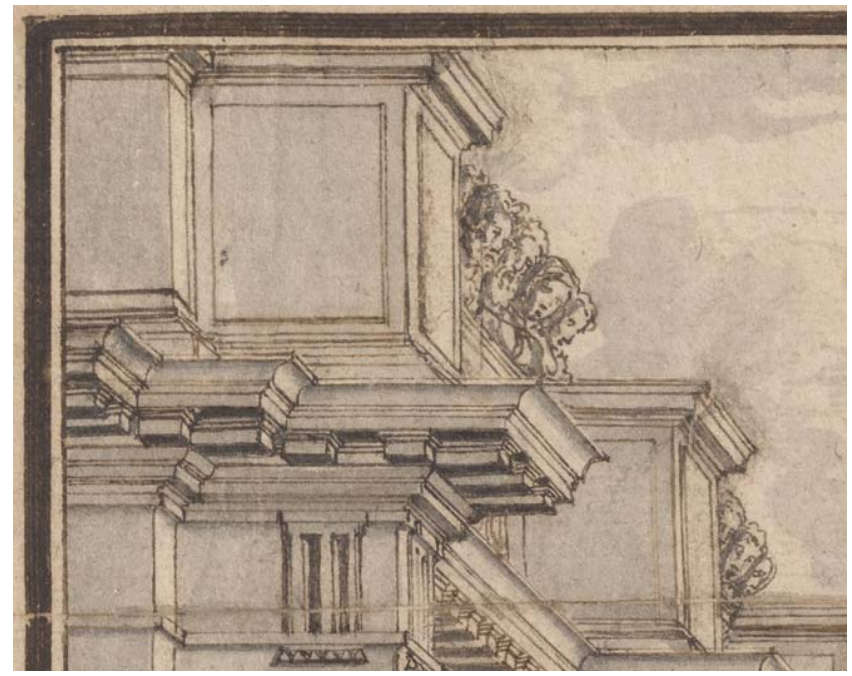

Fig. 17 Torelli, opera box detail in 'Royal Entry' (photo: Morgan Library \& Museum, Gift of Mrs. Donald M. Oenslager, 1982, 1982:75:636, photography by Steven H. Crossot, 2014)

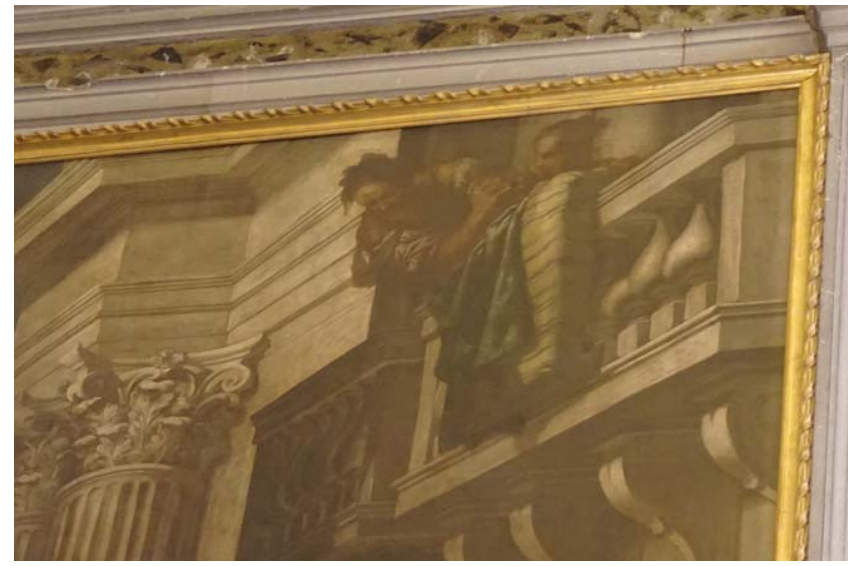

Fig. 18 Zanchi, opera box detail (photo: author)

boxes (known as palchi) that provided their inhabitants with privileged, unimpeded viewing sites (Fig. 17). Painted spectators who lean out from balconies in Negri's and Zanchi's paintings also appear at the upper corner of each work, along the sides that meet the lowest point of the stairway (Figs. 18 and 19). The position of these figures situated where confratelli traveling up the stairs would first enter, as well as the upward orientation of their gazes toward the stairs' apex, establishes immediately a relationship between viewing and acting. These 


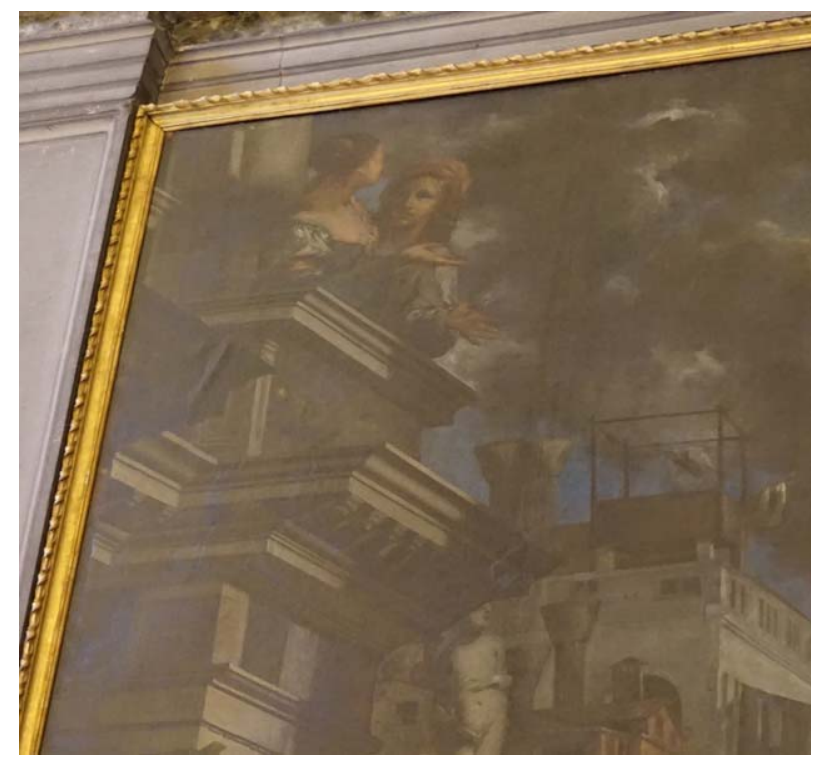

Fig. 19 Negri, opera box detail (photo: author)

opera box inhabitants connect with viewers, becoming their painted analogues, and reinforce Zanchi's use of the stairwell architecture to create an immersive experience for those travelling the stairs.

In Zanchi's painting, two women peer over a balcony at the horrors below. A grimy blanket and mattress have been draped over the edge of the parapet, indicating that these objects have been contaminated by pestilence and placed there for disinfection by fresh air. The women's dishevelled hair and looks of concern - one wrings her hands in dismay - suggest that while they are observers of the drama taking place at street level, they are also implicated in the danger. By contrast, the opera-box-like observers in Negri's The Madonna Saves Venice from the Plague of 1630 appear disengaged from the primary narrative action of the painting they inhabit. In the upper left corner of this composition, the woman and man at the balcony are engrossed, as if discussing the plague scene below. They do not look at the city or intercessors, but at one another, gesticulating as though commenting on the action. Dressed in fine clothes and displaying calm demeanour, they conduct themselves like audience members. Their greater detachment from the scene is consistent with the allegorical character of Negri's work.

Similar ploys for audience inclusion, paired with the anachronistic splicing of a narrative, historical time with that of the present-day spectators are found throughout operas of this period. In the formative productions of 
the 1640s-1660s, audiences were delighted by dramatic themes in libretti that juxtaposed stories of the classical world with political and social concerns in contemporary Venice. ${ }^{36}$ The prologues of many operas from this period referred to current events in the city, especially the War of Candia, in which Venice fought to maintain control of Crete over encroaching Ottoman forces. Allusions to Venice as a paragon of order and justice sprang up in these libretti, which sometimes called out 'the Turks' explicitly as a bellicose and threatening outside force. In the prologue of the 1662 performance of Cleopatra, for example, Jove complains of the unceasing state of war in Venice, offering to lend his thunderbolts to help: '. . à l'armi/a l'ire/contro l'empio Ottoman Veneti Eroi/Ecco dispiego il volo,/Anch'io trà voi/Porto miei sdegni à rintuzzar l'ardire./Creta è mia...'.37

The fantastical overlay of the antique past with the early modern present was a popular manoeuvre in these early opera performances, not only in sung content, but also in stage design. As noted by Ellen Rosand, one of the expansive sets designed by Giacomo Torelli for the 1642 performance of Bellerofonte featured a backdrop that lifted behind the depiction of ancient ramparts and moored ships to reveal Venice's Piazza San Marco, complete with campanile, Ducal palace, and the two columns that framed public spectacles (Fig. 20). The implication was that Venice had just emerged from the sea, prompting the actors on stage portraying ancient Roman gods and allegorical figures to sing a hymn celebrating the city for its noble character and worldwide admiration. ${ }^{38}$ No stage sets from this period survive, and scholars have had to rely upon prints and drawings for visual information regarding the stages of seicento operas, as well as descriptions written in libretti and scenarios. It is thus difficult to assess the frequency with which depictions of seventeenth-century Venice were included in set designs imaging the classical world. However, from the recurrent allusions to the city found in libretti, it is reasonable to suggest that the effect used in Bellerofonte was not singular.

Another method of conjuring early modern Venice within the imaginary worlds of seicento opera involved the performers. Actors in these early productions sometimes engaged in asides with audiences, breaking the so-called fourth wall and disrupting the narrative fiction. Of the celebrated La finta pazza, Rosand has noted this opera's self-referential approach to including audiences in the performance and consciously drawing attention to the status of actors playing a role, citing what she calls a series of 'plays-within-a-play' that interrupted the narrative flow. Anna Renzi, who became opera's first celebrity prima

${ }^{36}$ The first written history of Venetian opera was published during the seventeenth century by Cristoforo Ivanovich, 'Memorie teatrali di Venezia', in Minerva al tavolino (Venice: Appresso Nicolò Pezzana), 1681. For secondary literature on the development of opera in seicento Venice, see Ellen Rosand, Opera in SeventeenthCentury Venice; Carmelo Alberti, 'L'invenzione del teatro', in Storia di Venezia: dalle origini alla caduta della serenissima, v. VII, La Venezia Barocca, eds. Gino Benzoni e Gaetano Cozzi (Rome: Istituto della Enciclopedia Italiana, Fondata da Giovanni Trecanni, 1997), 701-58; and Glixon and Glixon, Inventing, 2006.

37 Rosand, 145-7.

38 Ibid., 134-6. 


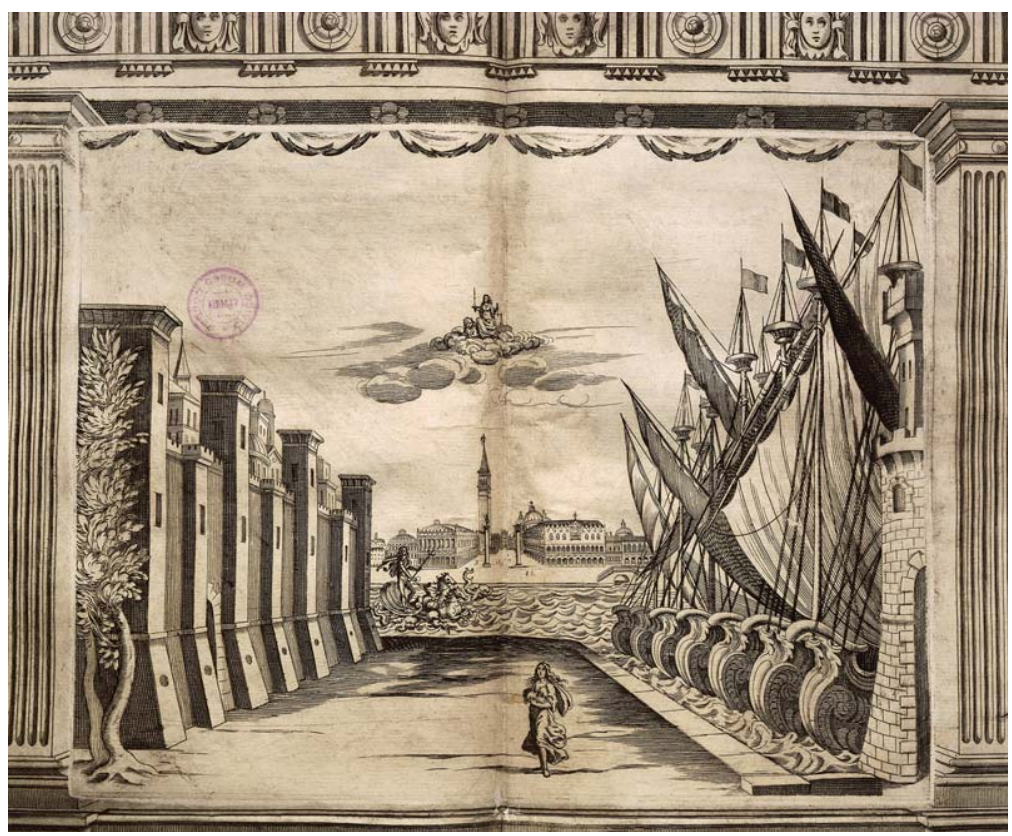

Fig. 20 Giacomo Torelli, stage set for 'Bellerofonte', 1642, engraving by Giovanni Giorgi (photo: (c) DeA Picture Library/Art Resource NY)

donna singing the lead role of Deidamia in this production, broke character at several points in the course of the performance, taking the audience's point of view, commenting coyly upon the scenery around her, and making a pun on the theatre's name. ${ }^{39}$ In addition, libretti from this period used subtler ways to bring seicento Venice into the mythologies. In Act Two of Bellerofonte, the hero makes a joke about plague - a topical and potentially weighty subject for Venetians. Reacting to a conversation in which the father and sister of his love interest Archimene discuss options for marrying her off to a mature candidate, Bellerofonte quips: 'Un vecchio? oh forsennata/Prima vorrei la peste,/Donna a Vecchio legata/Sempre ha vigilie, o feste. ... 40

These small but pervasive eruptions of the Venetian here-and-now within the staged classical world placed spectators in an oscillating relationship between passive and active viewing. In his painting for the Scuola Grande di San Rocco, Antonio Zanchi adopted a similar device. By creating a composition that disclosed its content sequentially, only as viewers moved through the stairwell, and by presenting the recent public health crisis in the city as a dramatic narrative, the painter conjured the 1630-31 plague outbreak as both lived reality and mythologized past. Thirty-five years had elapsed between the end of this

39 Ibid., 113-4.

${ }^{40}$ Vincenzo Nolfi, Bellerofonte (Venice: Appresso Gio. Battista Surian, 1642), 75. 
epidemic and Zanchi's commission at the Scuola. In this time, the city had made significant recoveries in its population and economy. A generation who may have had no first-hand experience of plague had reached adulthood in Venice. Zanchi's painting - intended to awe, to repulse, and to move viewers to greater sensations of piety - is a work very different from devotional objects created during plague outbreaks that served an immediate protective or apotropaic function. With the temporal distance between the 1630-31 epidemic and its memorialization in the San Rocco stairway, an interpretive space opened that allowed the painter to create an aestheticized narrative of the event. The pizzigamorti, the dead, the dying, and the hopeful became vehicles through which viewers could enter the scene on their progression up the stairs and visualize themselves in a world no longer present.

\section{DYNAMIC SPECTATORSHIP AND PUBLIC SPECTACLE IN VENETIAN PAINTING}

Seicento opera's dynamic modes of viewing and curated magnificence, however influential, were not the only, nor even the primary, sources for Zanchi's painting at the Scuola Grande di San Rocco's meetinghouse. The innovations found in Venetian opera grew out of a much deeper tradition of spectacle and performance developed over the previous two centuries in the city, including State-sponsored ceremonies, confraternal processions, and events related to Carnevale, which ran concurrently with opera season. Several of the compositional strategies used in The Virgin Appears to the Plague-Stricken that can be linked to opera productions were also part of established practices in Venetian painting and viewership.

Though opera boxes as an architectural phenomenon developed in Venice concurrently with the genre and became an integral part of a new language of theatre design, elevated viewing spaces that afforded their inhabitants exclusive vantage points at a remove were not new. ${ }^{41}$ Eugene Johnson has traced the evolution of opera boxes in Venice and suggests that this mode of viewing using stacked, enclosed spaces surrounding and surmounting the parterre (in distinction to the amphitheatre-style exemplified by structures like Palladio's Teatro Olimpico) developed out of precedents specific to the city. ${ }^{42}$ Venetians had been accustomed to using the balconies, parapets, and large windows of case, civic buildings, and other private structures as segregated spaces from which to view the many organized spectacles and ceremonies in the city. Johnson cites a conspicuous example: the balconies found in the upper story of Sansovino's Biblioteca Marciana, which look down upon the Piazzetta and the two columns that frame the Bacino view (Fig. 21). ${ }^{43}$ Since the middle of the sixteenth

\footnotetext{
41 Glixon and Glixon, 'The Boxes: A Major Source of Income', in Inventing, 17-33; and Eugene Johnson, 'The Short, Lascivious Lives of Two Venetian Theaters, 1580-85', Renaissance Quarterly, 55 (2002), 936-68.

${ }^{42}$ Eugene Johnson, 'Jacopo Sansovino, Giacomo Torelli, and the Theatricality of the Piazzetta in Venice', Journal of the Society of Architectural Historians, 59 (December 2000), 436-53.

43 Johnson, 'Lascivious Lives', 946.
} 


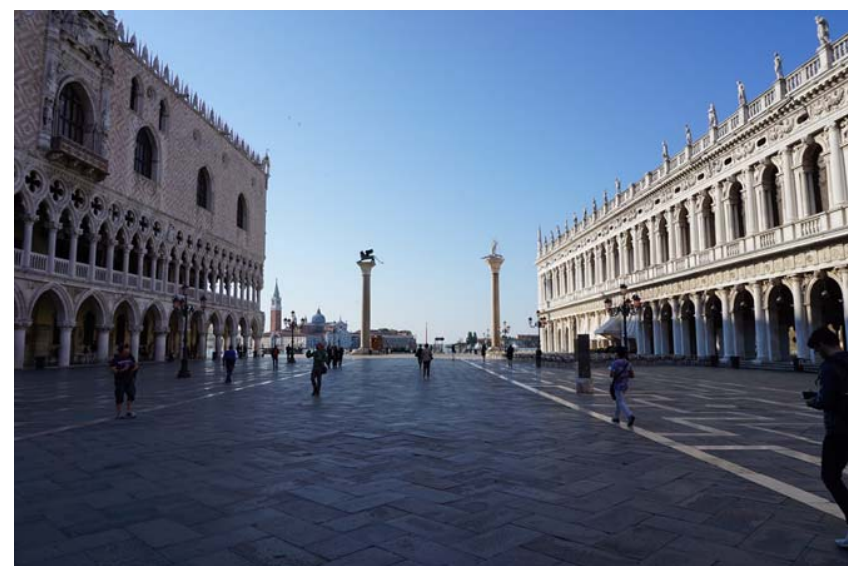

Fig. 21 Piazzetta with Biblioteca Marciana (right) and Palazzo Ducale (left) (photo: author)

century, procurators and other privileged spectators had used these balconies as prime viewing sites for the State-run spectacles, celebrations, and executions that took place in this important civic space. Elsewhere in the city, the windows and balconies overlooking bridges on which Venice's famous bridge fights took place served a similar function, and in fact, were rented out at high prices in the seventeenth century to viewers keen to have an unimpeded, bird's eye view of the battles. ${ }^{44}$ One of these popular fights is depicted in an engraving by Giacomo Franco produced in the 1610 series Habiti d'uomini e donne venetiane, showing combatants tumbling from the bridge while scores of onlookers fill the streets and canals to cheer them on. Spectators peering down from the windows of surrounding buildings watch with contrasting serenity (Fig. 22).

The phenomenon of active viewing and its links to ceremony and spectacle had been represented in Venetian painting since the late fifteenth century. The scuole grandi in particular commissioned extravagant painting cycles that depicted civic rituals in the city, engaging with ideas of access and viewership. In embellishing the stairway of the Scuola Grande di San Rocco, Antonio Zanchi had numerous precedents - large-scale paintings representing narrative histories from Venetian artists such as Gentile Bellini, Carpaccio, Titian, and, of course, Tintoretto. ${ }^{45}$ Two paintings from the cycle commissioned by the Scuola Grande di San Giovanni Evangelista in the 1490s to decorate their oratory, The Miracle of the Relic of the Holy Cross in Campo San Lio by Giovanni Mansueti and Gentile Bellini's famed Procession in the Piazza San Marco, exemplify models of engaged viewing (Figs. 23 and 24). In these works, painted spectators positioned in windows act as

\footnotetext{
44 Robert C. Davis, The War of the Fists: Popular Culture and Public Violence in Late Renaissance Venice (New York and Oxford: Oxford University Press, 1994), 'The View from the Balcony', 129-72; Johnson, 'Lascivious Lives', 946.

45 The pre-eminent study on this topic remains Patricia Fortini Brown's Venetian Narrative Painting in the Age of Carpaccio (New Haven: Yale University Press), 1988.
} 


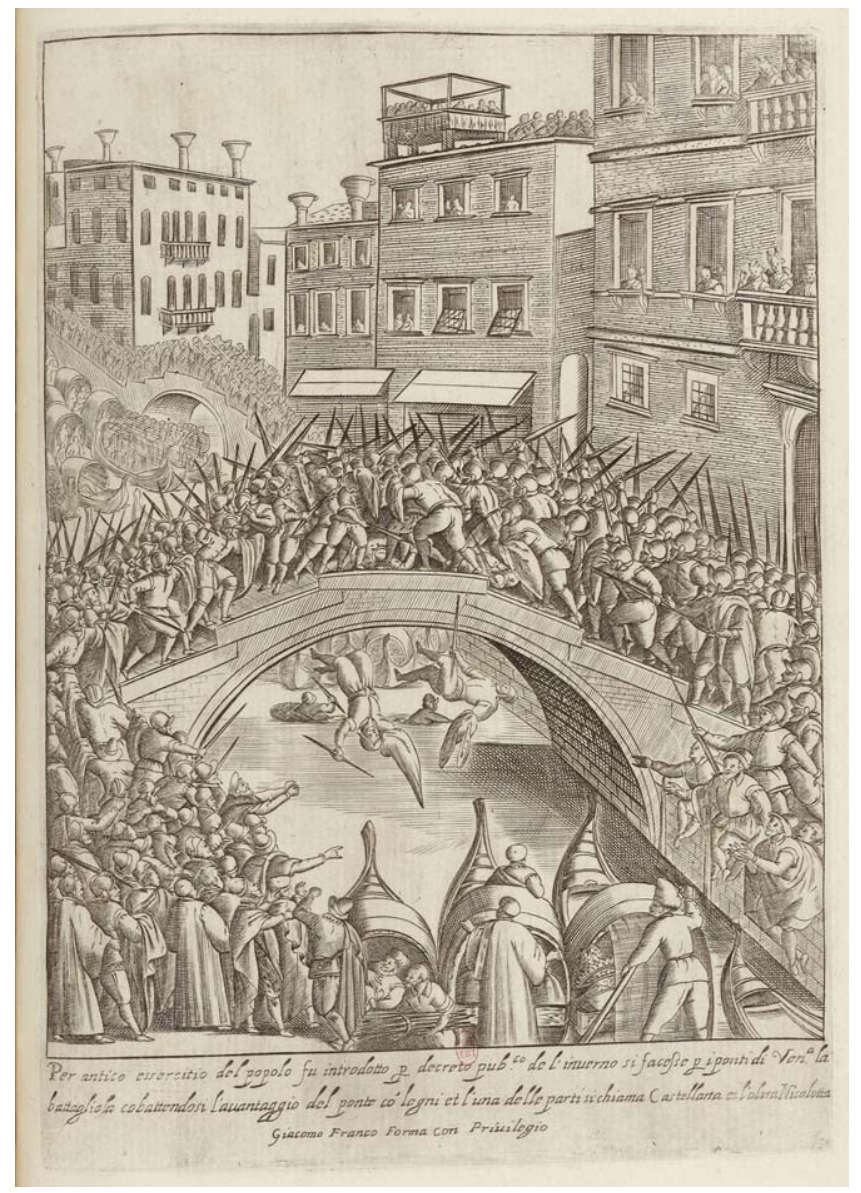

Fig. 22 Giacomo Franco, 'The Battle of the Sticks', from 'Habiti d'uomini e donne Venetiane', engraving, $23.2 \times 16.1 \mathrm{~cm}$, c.1610 (photo: Bibliothèque nationale de France)

witnesses to either a miracle enacted by the true cross, or as members of the throngs of devotees who have gathered in veneration of the relic. In Bellini's work, women gaze from the upper story of the Procuratie Vecchie at the procession below, while in Mansueti's view, the windows of every building proximal to the miracle on the bridge become a mosaic of tiny figures peeping out. ${ }^{46}$

A more sophisticated conception of embodied spectatorship was introduced in the following century in Titian's The Presentation of the Virgin in the Temple of 1534-38 for the albergo of the Scuola Grande di Santa Maria Carità, a painting

${ }^{46}$ Patricia Fortini Brown and Eugene Johnson have both examined these works with respect to their engagement with spectatorship in early modern Venice. See Brown, Venetian Narrative Painting, 'The Sacred in the Profane', 135-64, and Johnson, 'Theatricality', 442-3. 


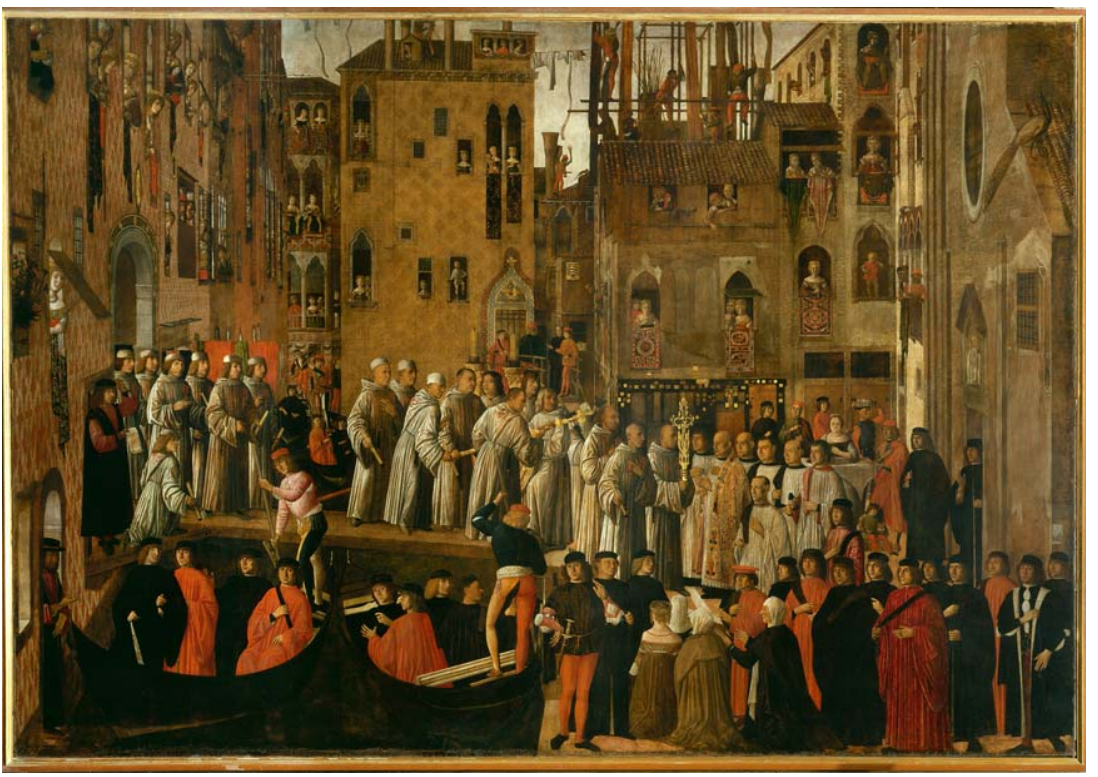

Fig. 23 Giovanni Mansueti, 'Miracle of the Relic of the Holy Cross in Campo San Lio', 1494, tempera on canvas, $318 \times 458$ cm, Gallerie dell'Accademia (photo: Cameraphoto Arte, Venice / Art Resource NY)

that influenced Zanchi in thematizing ascent along a stairway (Fig. 25). ${ }^{47}$ While Titian continued the tradition of depicting observers of the narrative action within the scene, he more effectively integrated the external viewer's visual engagement with the painting. In Titian's composition, the young Virgin ascends the grand stairs leading to the Temple of Solomon, isolated by the golden glow of sacrality and her commanding, yet diminutive appearance. Distinct from the previous century's confraternal paintings that used extensive detail to achieve a reportage-like verism, Titian has composed a work with a clear point of narrative focus and emphasis on psychological impact. The number of buildings framing the scene has been reduced, but their scale has increased, resulting in a monumentality that, when paired with the singular presentation of the tiny Virgin, creates a strong sense of the theatrical. Rendered this way, the city resembles Sebastiano Serlio's drawings of stage sets that used precise geometry to achieve the vanishing point perspective ubiquitous in set design for theatre productions of this period, and later, in opera settings (Fig. 26). Spectators who lean from the windows and balcony of the adjacent building heighten this effect. The most compelling aspect of Titian's engagement with spectatorship in The Presentation of the Virgin, however, is his consideration of viewers' position within the albergo. The painting's large scale and

\footnotetext{
${ }^{47}$ For work on this painting, see David Rosand, 'Titian's Presentation of the Virgin in the Temple and the Scuola della Carità', Art Bulletin, 58 (March 1976), 55-84.
} 


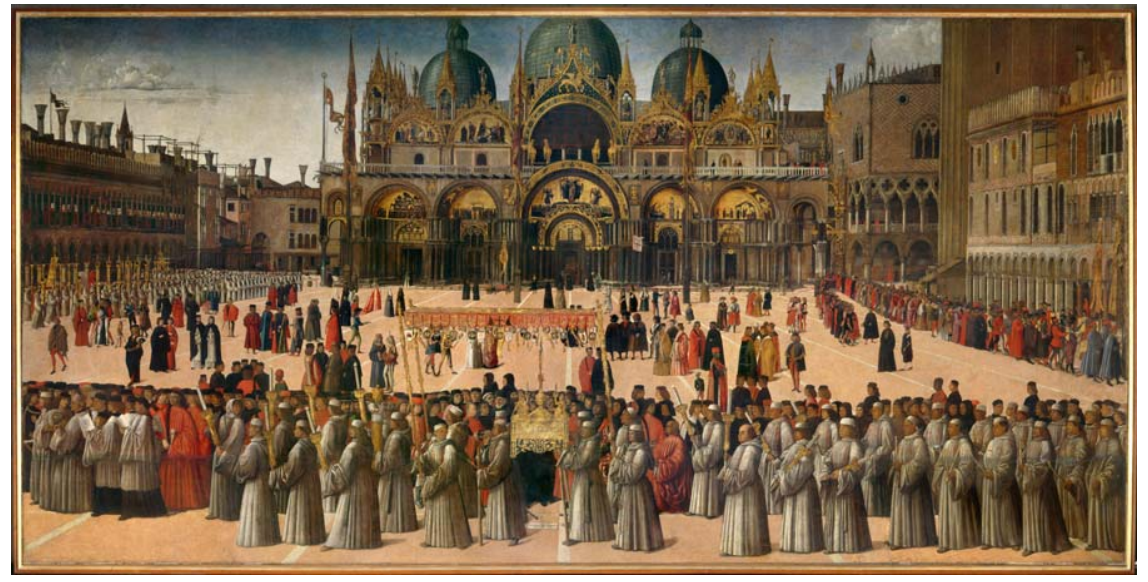

Fig. 24 Gentile Bellini, 'Procession of the Relic of the True Cross in the Piazza San Marco', 1496, oil and tempera on canvas, $367 \times 745 \mathrm{~cm}$, Gallerie dell'Accademia (photo: Cameraphoto Arte, Venice / Art Resource NY)

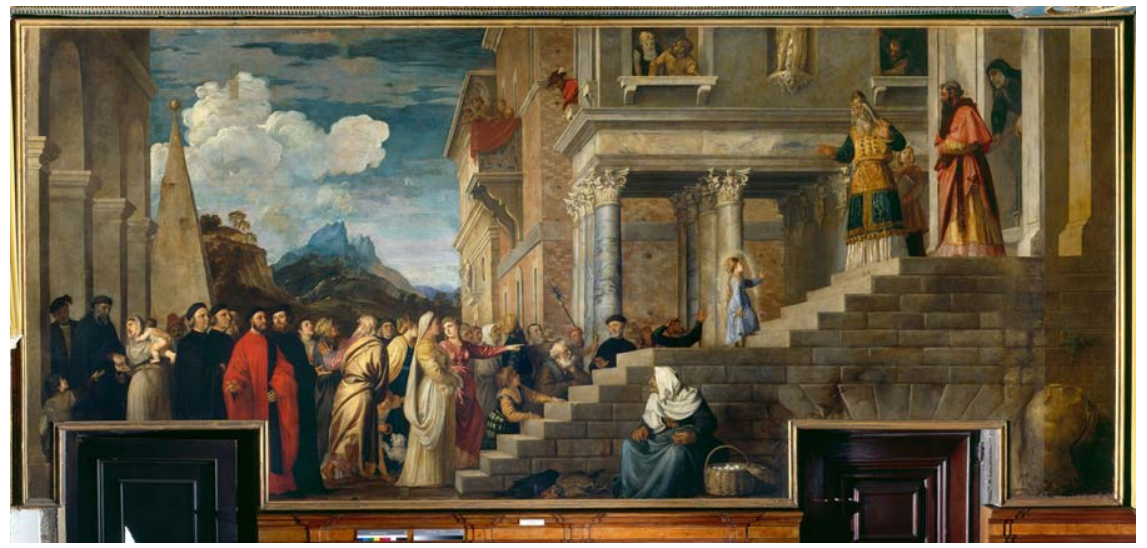

Fig. 25 Titian, 'Presentation of the Virgin in the Temple', 1534-8, oil on canvas, $345 \times 775 \mathrm{~cm}$, Gallerie dell'Accademia (photo: Cameraphoto Arte, Venice / Art Resource NY)

horizontal orientation, paired with the room's low ceiling, resulted in a composition that required the viewer to look up slightly to 'enter' the pictorial space and 'join' the crowd at the bottom of the depicted stairs, before allowing his or her eyes to travel the Virgin's path up the steps toward the temple. From here, the visual ascension is heightened by the diagonal thrust of the temple steps, the internal spectators distributed at varied elevations, and the architectural façade at the left that returns the eye to the starting point at street level. Through rendering the perspective of his canvas to align with the room's proportions and the vantage point of viewers within it, Titian has manipulated the space to create a sense of movement and progression, experienced virtually, through paint alone. This 


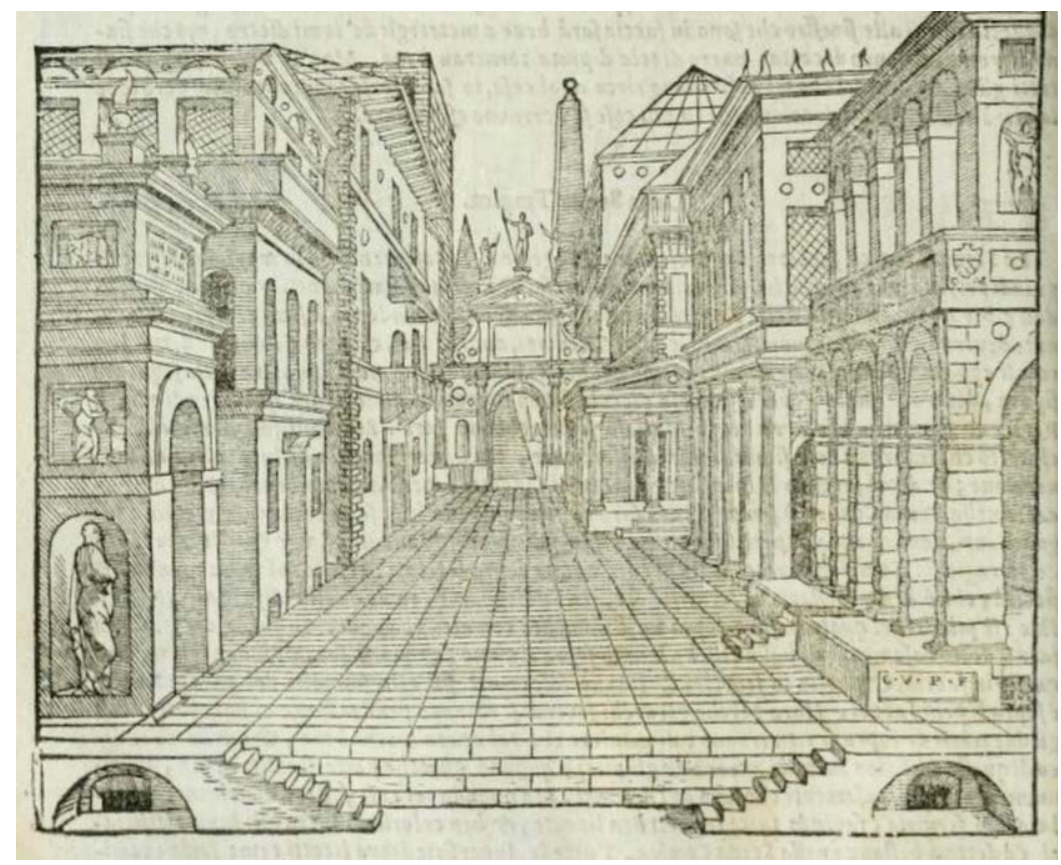

Fig. 26 Sebastiano Serlio, "Della scena tragica" in 'Tutte l'opere d'archittetura et prospetiva', Book II (Venice: Giacomo de' Franceschi, 1618), 46v. (photo: Internet Archive, public domain)

work represents an important model for Zanchi who, a century later, was provided with an actual stairway in which to position spectators - to orchestrate for them a physical course of ascension and sequential viewing.

Antonio Zanchi's rendering of the 1630-31 plague for the Scuola Grande di San Rocco should be understood as a modernized take on the tradition of narrative istora at the Venetian confraternities. The documentary aspects of Zanchi's painting - his chronicling of the emblematic pizzigamorti, the proliferation of contaminated materials in the city, and the residents' pleas for succour - are portrayed in a style using greater drama and more emphasis on active viewing than that of past artists working at the scuole grandi. Zanchi sought not to simply represent plague-stricken Venice of the past with eyewitness-like detail, but to recreate for viewers the experience and sensation of inhabiting the city in this dire moment, followed by a satisfying triumph over the adversity. Zanchi's work is participatory in ways that earlier precedents were not. His retrospective look at plague in Venice tapped into established traditions of ritual performance and viewership in the city, resulting in an innovative composition that allowed spectators to prevail over plague in perpetuity. 